\title{
Isothermal Amplification and Quantification of Nucleic Acids and its Use in Microsystems
}

\author{
Vicky Tröger ${ }^{1,2 *}$, Katja Niemann ${ }^{1,3}$, Cornelia Gärtig ${ }^{1,4}$ and Dirk Kuhlmeier ${ }^{1}$ \\ ${ }^{1}$ Department of Diagnostics, Nanotechnology Unit, Fraunhofer Institute for Cell Therapy and Immunology, Leipzig, Germany \\ ${ }^{2}$ Department of Chemistry and Mineralogy, Institute of Analytical Chemistry, University of Leipzig, Germany \\ ${ }^{3}$ Beuth University of Applied Sciences Berlin, Germany \\ ${ }^{4}$ Friedrich Schiller University Jena, Germany
}

\begin{abstract}
Nucleic acid amplification technologies (NAATs) offer the most sensitive tests in the clinical laboratory. These techniques are used as a powerful tool for screening and diagnosis of infectious diseases. Isothermal methods, as an alternative to polymerase chain reaction (PCR), require no thermocycling machine and can mostly be performed with reduced time, high throughput, and accurate and reliable results.

However, current molecular diagnostic approaches generally need manual analysis by qualified and experienced personal which is a highly complex, time-consuming and labor-intensive task. Thus, the demand for simpler, miniaturized systems and assays for pathogen detection is steadily increasing. Microfluidic platforms and lab-on-a-chip devices have many advantages such as small sample volume, portability and rapid detection time and enable point-of-care diagnosis.
\end{abstract}

In this article, we review several isothermal amplification methods and their implementation in microsystems in relation to quantification of nucleic acids.

Keywords: Isothermal amplification methods; Lab-on-chip; pointof-care testing; Healthcare; Nucleic acid; Microfluidics; Miniaturization

\section{Introduction}

The idea of miniaturization of available technologies was created by Richard P. Feynman in his famous lecture in 1959, who started the ball rolling [1]. In 1982, Petersen described the entire potential of microsystem technology, and in the following years and decades a wealth of concepts for microsystems, possible applications and new miniaturized systems were developed by today [2]. This technology can combine electronic and non-electronic functions and achieve new mechanical, optical, fluidic, electronic functionalities or miniaturize already established applications. When integrating sensors and actuators a direct analysis can bring decisive advantage [3]. The microsystems in medicine and biology often belong to one of the four important areas of application: diagnostics, drug delivery, minimally invasive surgery, or neural prosthetics and tissue engineering [4]. Concerning the diagnostic area there are three categories, most of the test systems are based on: paper-based analytical devices, lab-on-chip, and micro total analysis system ( $\mu \mathrm{TAS})[5]$.

Miniaturized systems for the analysis of genetic sequences are a major cornerstone for the development and marketability of pointof-care (POC) devices [6]. These devices can be characterized by a high integration of several functionalities onto a single platform, e.g. cumbersome lab processes like sample preparation, nucleic acid amplification and detection. An integrated microfluidic device, for example, incorporates many of the required components of a typical room-sized laboratory on a small chip [7]. They offer the possibility to leave a clean lab environment, because one major target is the incorporation of as many necessary reagents as possible on the device. Therefore, contaminations are greatly reduced.

Microsystems lead to portable, easy-to-use devices, which might also be applied by lay users. These systems have shown that the analysis of samples can be moved from a specialized laboratory closer to the patient, aiming at POC, or even to in-field testing [8,9].

However, the key areas of application for integrated and miniaturized systems can be diverse. The majority of publications are focussed on clinical diagnostics including foodborne organisms for environmental monitoring [10-12]. In case of an infectious disease, cultivation and phenotypic characterization are still the standard methods of microbiologists which need days up to weeks to obtain a diagnostic result. Hence, scientists started to make use of nucleic acid amplification methods to accelerate the analysis. The most widespread and well known technique for this purpose is the polymerase chain reaction (PCR) [10,13], which exploits the activity of the DNA polymerase. The method is based on a thermal cycling process consisting of repeated cycles of heating and cooling steps allowing for DNA melting, sequence specific primer binding and enzymatic amplification of the target nucleic acid. The quantitative assessment of target copies is possible by using a real-time PCR approach, where a concentration dependent signal (e.g. fluorescence) increases over time [14]. The latter enables the user to easily assess the pathogen load of patient samples [15-18]. Since the first example of a PCR on a miniaturized system in $1994[19,20]$, numerous devices were presented, which integrate not just the amplification, but also sample preparation and detection steps [9,21-28]. Just a few of those microsystems have reached the market so far, but some have shown a fascinating potential to replace the classical laboratory-oriented state-of-the art [29-33].

Miniaturization of biochemical reactions leads to major advantages, where a lower amount of valuable clinical sample and reagents is just one: approximately $1 / 1000$ of the volume used in conventional lab

*Corresponding author: Vicky Tröger, Department of Diagnostics, Nanotechnology Unit, Fraunhofer Institute for Cell Therapy and Immunology, Leipzig, Germany, Tel: 49-341-35536-9329; E-mail: vicky.troeger@izi.fraunhofer.de

Received January 16, 2015; Accepted March 23, 2015; Published April 10, 2015

Citation: Tröger V, Niemann K, Gärtig C, Kuhlmeier D (2015) Isothermal Amplification and Quantification of Nucleic Acids and its Use in Microsystems. J Nanomed Nanotechnol 6: 282. doi:10.4172/2157-7439.1000282

Copyright: ( 2015 Tröger V, et al. This is an open-access article distributed under the terms of the Creative Commons Attribution License, which permits unrestricted use, distribution, and reproduction in any medium, provided the original author and source are credited. 
setups has been shown to obtain a similar result [34]. A smaller heat capacity allows for rapid changes in temperature beneficial for the PCR time as well as a higher parallelism of multiple genetic samples [34].

However, a major drawback of the integration of PCR to microsystems is the necessity of sophisticated instrumentation. The reaction requires a thermal cycling instrumentation, space and considerable expertise [35]. Therefore, isothermal reactions for the target specific amplification are alternative and valuable methods for the simplification of diagnostic devices.

This review will discuss different isothermal amplification methods for nucleic acids and their integration into miniaturized systems. Some already published reviews gave a broad overview of that field [36-39], however, we will have a special view on the most recent strategies to amplify and quantify target molecules in samples. Since the focus of this article is the integration of these technologies into miniaturized systems, the molecular background of the isothermal methods is just briefly described. Comprehensive references will direct the reader to the more detailed descriptions of the biology behind the amplification reactions.

\section{Strategies to Miniaturize Isothermal Amplification Reactions}

\section{LAMP: Loop-mediated isothermal amplification}

The loop-mediated isothermal amplification LAMP was firstly described in 2000 and developed by the Japanese Eiken Chemical Co, Ltd. (Tokyo) [40]. Various publications on LAMP describe it as a very promising tool for the use in microsystems. In principle, the reaction employs a DNA polymerase with strand displacement activity and 4 or 8 specially designed primers that recognize 6 or 8 distinct sequences on the target DNA under isothermal conditions $\left(60-65^{\circ} \mathrm{C}\right)$. On average, the reaction runs for about 60 minutes [40-42], showing an extremely high specificity [43]. Also, LAMP method has a high amplification efficiency that allows for the synthesis of large amounts of DNA in a short time. Its detection limit is a few copies per reaction and therefore is comparable to that of PCR [40]. For the assay performance, only a heating block at a constant temperature or a water bath is necessary. Furthermore, LAMP can be adapted to RNA templates in combination with a reverse transcriptase under the same working temperature and without additional time for transcription [44].

LAMP amplification products can be detected either by gel electrophoresis, real-time monitoring of turbidity with a turbidimeter $[43,45]$ or simply with the naked eye. During the reaction, a large amount of DNA is synthesized, yielding a large pyrophosphate ion by-product. It was observed that pyrophosphate forms an insoluble, observable white precipitate with divalent metallic ions [43]. Another visual detection method based on the formation of pyrophosphate can be accomplished by using the fluorescent metal indicator calcein, which binds free calcium ions. Calcein has been used for the real-time detection of DNA formation during LAMP [46]. Further methods apply intercalating DNA dyes such as SYBR Green I [47], FDR [48], or oligonucleotide probes labeled with different fluorescent markers as well as low molecular weight cationic polymers such as polyethylenimine [49].

To perform the reaction, a set of two specially designed inner and outer primer pairs and a DNA polymerase with strand displacement activity are required for the DNA synthesis. The initial reaction steps are illustrated in Figure 1. DNA regions F3 and R3 are complementary to $\mathrm{F} 3 \mathrm{c}$ and $\mathrm{R} 3 \mathrm{c}$ on the template, respectively. The $\mathrm{F} 2$ region in the forward inner primer FIP is complementary to the F2c region followed by the F1c complementary to F1 of the target DNA. The same principle is used to design the backward primer. As a result, these four primers recognize six distinct sequences which ensure high specificity for target amplification. Moreover these primers enable generation of a stem-loop DNA for subsequent complex LAMP cycling including selfpriming reactions. A mixture of DNA, differing in the number of loops and lengths of the stem loop, are produced as final products.

Due to the easy operation, high sensitivity and specificity, LAMP is an excellent choice for point-of-care applications. Thus, many microsystems that combined LAMP with different detection methods, newly designed lab-on-chips, microfluidic cartridges and automated techniques were reported. In many studies, the LAMP amplification signals were already detected after 15-40 minutes after the thermal reaction started [50-54].

The preferred and the most sensitive method for detection is based on fluorescence (with SYBR green, SYTO green or EvaGreen as fluorescent dyes) that can be detected as early as 15 minutes after the thermal reaction starts. For calcein, a limit of detection (LOD) of about 270 copies/ $\mu \mathrm{L}$ was described [55]. Instead of fluorescence, Mori et al. developed a device capable of measuring the turbidity of multiple samples simultaneously. While maintaining a constant temperature, the LAMP reaction was followed in real-time by measuring changes in turbidity of solution [43].

Hsieh et al. presented a microfluidic LAMP device with an integrated electrochemical sensor [56]. Methylene blue, an electrochemically active DNA-binding compound, was added to the reaction mixture. A drop of current was measured due to the intercalation of methylene blue into the newly formed DNA, giving a LOD of 16 copies for $C$. enterica [56]. Ahmed et al used ruthenium hexaamine molecules as the redox active compounds for electrochemical sensing. The sensitivity referred to less than $24 \mathrm{CFU} / \mathrm{mL}$ for bacteria and $8.6 \mathrm{fg} / \mu \mathrm{L}$ for DNA [57]. Chuang et al. demonstrated a simple, low-cost surface plasmon resonance sensing cartridge based on the LAMP method for the one-site detection of hepatitis B virus [58-66]. The HBV template could be detected by an SPR-LAMP system in 17 minutes even at the detection limit of $2 \mathrm{fg} / \mathrm{mL}$.

Several LAMP systems of on-chip detection modules were also combined with heating modules [52-54]. For the purpose of complete automatic control of the assay, Wang et al. integrated sample pretreatment into the microfluidic LAMP device by using magnetic beads and a specially designed isolation membrane $[53,54]$. The entire diagnostic protocol including sample pre-treatment, LAMP reaction and optical detection was automatically completed in 60 minutes, which was twice as fast as with conventional devices [53].

Table 1 lists various strategies for the application of LAMP in microsystems which were developed in the last three years.

\section{RPA: Recombinase Polymerase Amplification}

RPA combines a low reaction temperature (about $37^{\circ} \mathrm{C}$ ) with short reaction duration and thus makes it ideal for POC tests. The method couples isothermal recombinase-driven primer targeting of the template material with the strand-displacement DNA synthesis. It was patented by Piepenburg et al. including a novel probe-based detection approach [67].

The RPA method amplifies DNA sequences by using a recombinase, DNA polymerase and single-stranded DNA-binding proteins (SSBs). 
Citation: Tröger V, Niemann K, Gärtig C, Kuhlmeier D (2015) Isothermal Amplification and Quantification of Nucleic Acids and its Use in Microsystems. J Nanomed Nanotechnol 6: 282. doi:10.4172/2157-7439.1000282

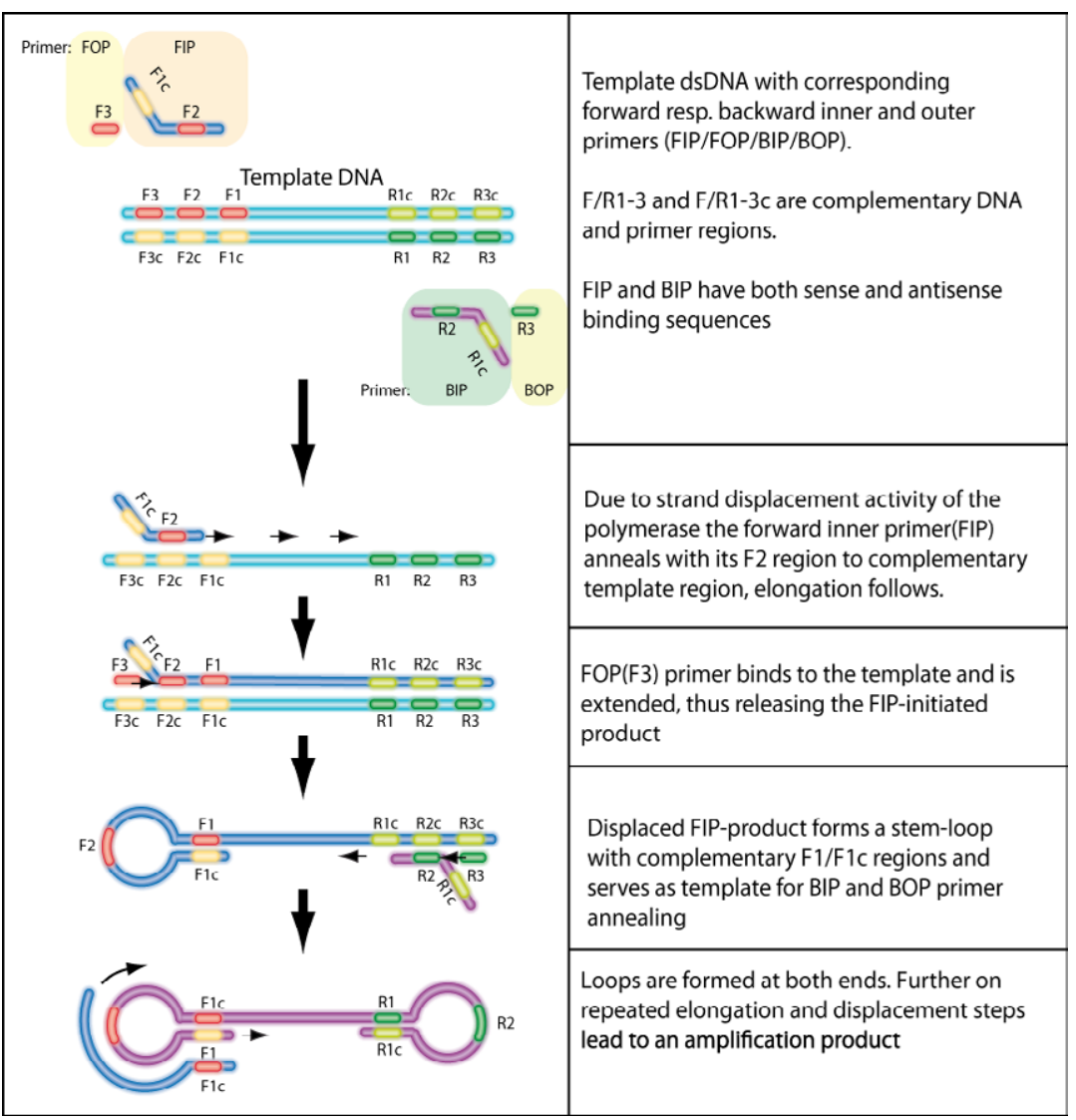

Figure 1: Initial steps of the LAMP reaction.

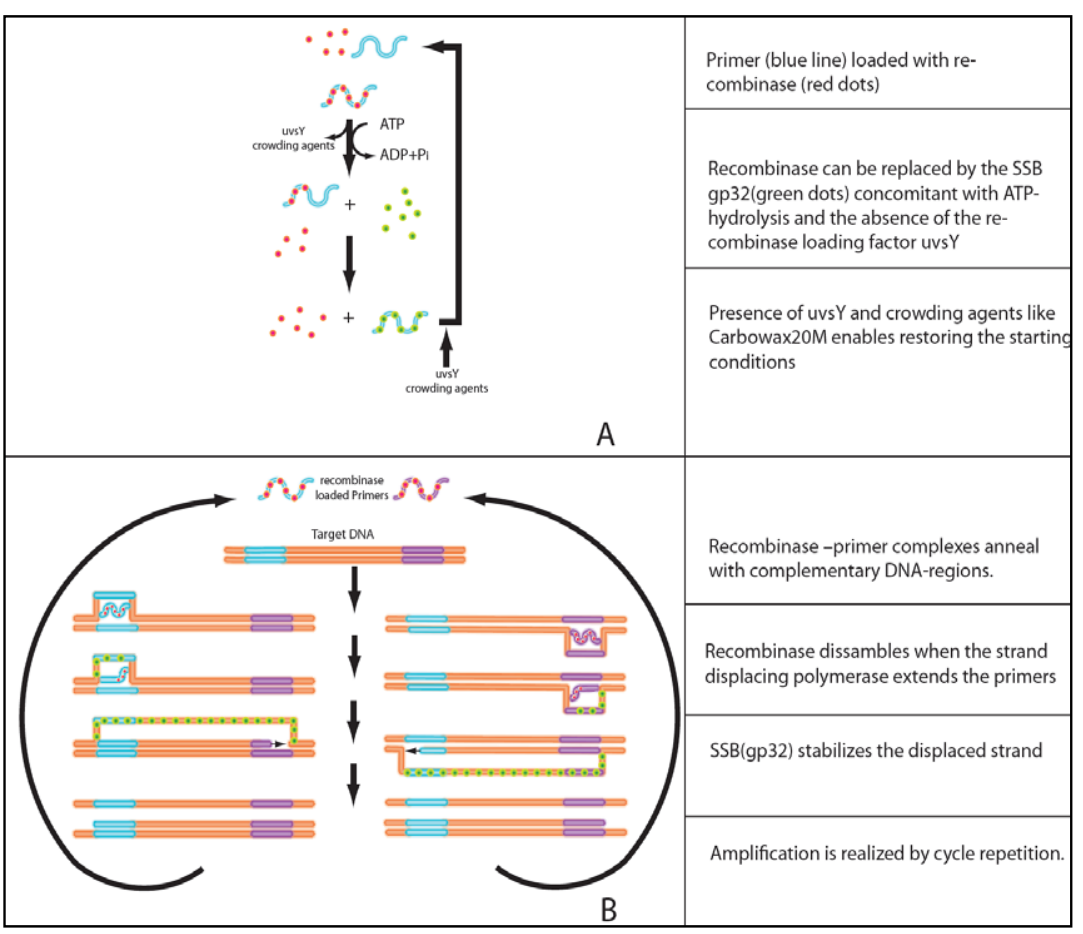

Figure 2: A) Combination of the primer-recombinase complex and replacement with SSBs; B) RPA cycle. 
Citation: Tröger V, Niemann K, Gärtig C, Kuhlmeier D (2015) Isothermal Amplification and Quantification of Nucleic Acids and its Use in Microsystems. J Nanomed Nanotechnol 6: 282. doi:10.4172/2157-7439.1000282

Page 4 of 19

\begin{tabular}{|c|c|c|c|c|}
\hline System design & Detection strategy & LOD & Target & Ref. \\
\hline $\begin{array}{l}\text { Microfluidic single chip consists of seven PDMS } \\
\text { microchambers with on-chip RNA purification, RT-LAMP } \\
\text { and optical detection }\end{array}$ & $\begin{array}{l}\text { RT-LAMP and } \\
\text { optical detection of turbidity change }\end{array}$ & $35 \mathrm{pg}$ & $\begin{array}{l}\text { RNA extracted from CymMV- } \\
\text { infected Phalaenopsis orchids }\end{array}$ & [59] \\
\hline LAMP combined with lateral-flow dipstick & Lateral flow dipstick & $<5 \mathrm{pg}$ & $\begin{array}{l}\text { IS6110 gene of } M . \text { tuberculosis } \\
178 \text { bp fragment }\end{array}$ & [60] \\
\hline $\begin{array}{l}\text { PDMS based microfluidic channels and membrane for three } \\
\text { microchambers with on-chip RNA extraction and RT-LAMP }\end{array}$ & Real-time fluorescence & $10-100 \mathrm{fg}$ & cDNA of NNV RNA1 & [53] \\
\hline $\begin{array}{l}\text { " } \mu \text {-LAMP"; PDMS-glass hybrid microfluidic chip with eight } \\
5 \mu \mathrm{l} \text { microchannels and on-chip real-time absorbance } \\
\text { detection device by integrated optical fibers }\end{array}$ & $\begin{array}{l}\text { Naked eye and real-time optical } \\
\text { detection of turbidity change }\end{array}$ & $10 \mathrm{fg}$ & 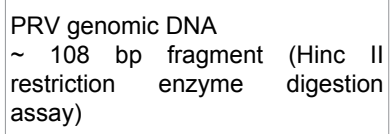 & {$[50]$} \\
\hline $\begin{array}{l}\text { Magnetic bead-based microfluidic chip; five PDMS } \\
\text { microchambers with on-chip cell lysis and DNA hybridization }\end{array}$ & Spectrophotometric analysis $\left(\mathrm{OD}_{260}\right)$ & $10 \mathrm{fg}$ & DNA of MRSA & [54] \\
\hline $\begin{array}{l}\text { Ten microchamber muLAMP system in a PDMS-glass } \\
\text { format }\end{array}$ & $\begin{array}{l}\text { Direct naked-eye determination and } \\
\text { SYBR green I fluorescence }\end{array}$ & $<10$ copies & $\begin{array}{l}\text { Conserved DNA fragments of three } \\
\text { human influenza A substrains and } \\
\text { ejaht important swine viruses }\end{array}$ & {$[50]$} \\
\hline $\begin{array}{l}\text { CCD-based fluorescence imaging system in disposable } \\
\text { COP-microchips; for ds-DNA standard dilution series: } \\
16 \text { circular wells with } 1 \mathrm{~mm} \text { diameter and } 2 \mu \mathrm{L} \text { volume per } \\
\text { well; for real-time LAMP: Seven V-shaped reaction wells } \\
\text { with a volume of } 2 \mu \mathrm{L} \text { per well; fabricated with } 100 \mu \mathrm{m} \text { thick } \\
\text { ZeonorFilm }\end{array}$ & $\begin{array}{l}\text { Real-time detection; fluorescence } \\
\text { imagining }\end{array}$ & Single copy & $\begin{array}{l}\text { Genomic DNA from } 12 \text { virulence } \\
\text { genes of major waterborne } \\
\text { pathogens }\end{array}$ & [61] \\
\hline $\begin{array}{l}\text { Novel SPR-LAMP microfluidic cartridge integrated with a } \\
\text { polycarbonate-based prism coated with a } 50 \mathrm{~nm} \text { Au film }\end{array}$ & Surface plasmon resonance (SPR) & $2 \mathrm{fg}$ & HBV fragment & [58] \\
\hline $\begin{array}{l}\text { Oxidized silicon well array ( } 4 \text { arrays of } 6 \times 6 \text { wells) with } \\
\text { dehydrated primers were covered with mineral oil; droplets } \\
(30 \mathrm{~nL}) \text { are arrayed with an automated microinjection } \\
\text { system }\end{array}$ & $\begin{array}{l}\text { Real-time fluorescence of } \\
\text { EvaGreen }\end{array}$ & Not specified & $\begin{array}{l}\text { stx2 for E. coli O157, hlyA for } \\
\text { Listeria monocytogenes, and invA } \\
\text { for Salmonella }\end{array}$ & [62] \\
\hline $\begin{array}{l}6 \times 8 \text { semisolid polyacrylamide gel post array; each post: } \\
670 \mathrm{~nL} \text { volume; Peltier element for heating, a diode laser } \\
\text { as an excitation source, and a CCD camera for detecting } \\
\text { fluorescence in real-time }\end{array}$ & $\begin{array}{l}\text { Real-time fluorescence of the dye } \\
\text { LCGreen Plus+, polymerized into } \\
\text { the gel }\end{array}$ & $63 \mathrm{fg}$ & $\begin{array}{l}\text { Six M. tuberculosis DNA samples } \\
\text { with variable concentrations } \\
\text { and target numbers of IS } 6110\end{array}$ & [63] \\
\hline $\begin{array}{l}46 \mathrm{~mm} \times 36 \mathrm{~mm} \times 3.4 \mathrm{~mm} \text { cassette consists of three solvent- } \\
\text { bonded layers of PC; valve was formed with a composite of } \\
\text { PDMS and highly expandable microspheres; on-chip real- } \\
\text { time monitoring }\end{array}$ & $\begin{array}{l}\text { Real-time fluorescence with a } \\
\text { portable, compact detector }\end{array}$ & 10 copies & E. coli DNA/RNA-fragments & [64] \\
\hline $\begin{array}{l}\text { PMMA cartridge; exothermic reaction between Mg-Fe alloy } \\
\text { and water as the heat source; reaction rate is controlled } \\
\text { by using a filter paper; the amplification chambers' } \\
\text { temperatures are regulated with a phase change material }\end{array}$ & $\begin{array}{l}\text { Visual fluorescent detection with } \\
\text { SYTO } 9 \text { Green by naked eye and/ } \\
\text { or recorded with a portable digital } \\
\text { camera }\end{array}$ & 10 copies & Fragment of $E$. coli & [52] \\
\hline $\begin{array}{l}\text { FTA (Flinders Technology Associates (Whatman FTA } \\
\text { membrane) disc was installed in the amplification reactor and } \\
\text { operated in a flow-through (filtration) mode; DNA (captured } \\
\text { on the FTA disc) were directly used as templates for LAMP } \\
\text { without a need for elution and transfer of nucleic acids }\end{array}$ & $\begin{array}{l}\text { Blue LED excitation light for end- } \\
\text { point detection with a } \\
\text { cell phone camera }\end{array}$ & Not specified & $\begin{array}{l}\text { Genomic DNA from mosquito } \\
\text { tissue (Anopheles gambiae and } \\
\text { An. grabiensis) }\end{array}$ & [65] \\
\hline $\begin{array}{l}\text { Single reaction chamber with an integrated, flow-through } \\
\text { FTO membrane for isolation, concentration and purification } \\
\text { of DNA/RNA; thermal control by an external film heater }\end{array}$ & Portable optical detection system & $<10$ HIV particles & $\begin{array}{l}\text { HIV particles suspended in raw } \\
\text { saliva }\end{array}$ & [66] \\
\hline
\end{tabular}

Table 1: Comparison between different LAMP devices.

A RPA cycle is initiated by the binding of a recombinase to the primers in the presence of ATP, as shown in Figure 2A. After the recombinaseprimer complex attaches sequence specifically to the double-stranded DNA, the 3'-ends of the primer are accessible to DNA polymerase. Its displacement activity creates a single strand, which is stabilized by SSBs. Both strands can be targeted, leading to an exponential amplification (Figure 2B).

Commercial Kits for RPA are available from TwistDX (Cambridge, UK). The Kits are conFigured for gel electrophoresis, lateral flow and fluorescence detection (www.twistdx.co.uk).
During the last years, RPA was described in some publications focusing on isothermal reactions for microsystems. Lutz et al. designed an integrated microfluidic assay based on RPA where all required dry and liquid reagents were pre-stored in the test carrier [68]. The fluidic cartridge included cavities for processing of up to 30 samples in parallel in separate $10 \mu \mathrm{L}$ microchambers. This technology allowed for the detection of the antibiotic resistance gene mecA of Staphylococcus aureus from $\leq 20$ starting copies in $<15$ minutes at a temperature of $37^{\circ} \mathrm{C}$.

A phaseguided passive batch microfluidic mixing chamber 
Citation: Tröger V, Niemann K, Gärtig C, Kuhlmeier D (2015) Isothermal Amplification and Quantification of Nucleic Acids and its Use in Microsystems. J Nanomed Nanotechnol 6: 282. doi:10.4172/2157-7439.1000282

Page 5 of 19

utilizing RPA was demonstrated by Hakenberg et al. The device was fabricated with a combination of dry film resist technology and direct wafer bonding. Fluorescent signals were measured directly on the chip afte one minute mixing [69].

Rohrmann and Richards-Kortum developed a paper- and plasticbased device that stored enzymes, mixed reagents, and supported RPA of HIV DNA [70]. This application was created to be compatible with DNA extraction from dried blood spots and detection using lateral flow strips. It indicated that isothermal, enzymatic amplification of DNA is practicable in a matrix-based format, serving as a new device for paperbased microfluidic techniques.

Digital amplification is an attractive option for quantitative analysis of nucleic acids. However, the nucleic acid template must be compartmentalized prior to adding initial reagents realizing digital RPA without false-positive results. Shen et al. developed a microfluidic digital RPA SlipChip for simultaneous initiation of over $1000 \mathrm{~nL}$ scale RPA reactions by adding a chemical initiator to each reaction compartment with a simple slipping step after instrument-free pipette loading [71]. Fluctuations of the incubation temperature ranking from $37^{\circ} \mathrm{C}$ to $42^{\circ} \mathrm{C}$ had no influence to the digital RPA. In order to monitor the generation of amplified target material, end-point fluorescence readout was realized by applying a fluorophore/quencher bearing probe which was cut enzymatically in response to sequence-specific binding to amplified DNA. This proceeding led to an increase in observable fluorescence as a result of separation of the fluorophore and quencher groups.

Table 2 presents diverse devices for RPA in microsystems which were developed in the last four years.

\section{NASBA: Nucleic acid sequence-based amplification}

Nucleic acid sequence-based amplification (NASBA), self-sustained sequence replication (3SR) and transcription mediated amplification (TMA) are very similar, based on same principle and derived from transcription based amplification system (TAS) described by Kwoh et al. [72]. NASBA was first described in 1991 [73], 3SR from Guatelli et al. [74] and TMA from Pfyffer et al. [75].

These types of isothermal amplification reactions combine three different enzymes to specifically amplify RNA or single-stranded DNA: an AMV (avian myeloblastosis virus) reverse transcriptase, RNase $\mathrm{H}$, and a T7 RNA polymerase simultaneously conduct a billion-fold

\begin{tabular}{|c|c|c|c|c|}
\hline System design & Detection strategy & LOD & Target & Ref. \\
\hline $\begin{array}{l}\text { Thermoformed foil-based centrifugal microfluidic lab-on-chip cartridge } \\
\text { including prestored liquid and dry reagents, and a commercial available } \\
\text { analyzer for incubation at } 37^{\circ} \mathrm{C} \text {; separate } 10 \mu \mathrm{L} \text { microchambers for } \\
\text { amplifying up to } 30 \text { samples in parallel }\end{array}$ & Real-time fluorescence & $<10$ copies & mecA of Staphylococcus aureus & [68] \\
\hline $\begin{array}{l}\text { Phase-quided microfluidic mixing chip; passive laminar flow mixing of two } \\
6.5 \mu \mathrm{L} \text { batches in a microfluidic chamber }\end{array}$ & $\begin{array}{l}\text { Inverted fluorescence } \\
\text { microscope }\end{array}$ & Not specified & Not specified & [69] \\
\hline $\begin{array}{l}\text { Paper and plastic device assembled by stacking components made of } \\
\text { acetate, double-sided adhesive, glass fiber matrix, and cellulose }\end{array}$ & $\begin{array}{l}\text { Lateral flow strips; visual } \\
\text { detection }\end{array}$ & 10 copies & HIV gag DNA & [70] \\
\hline $\begin{array}{l}\text { Microfluidic digital RPA SlipChip; } 1550 \text { reaction compartments of } 9 \mathrm{~nL} \\
\text { each, with } 2 \text { sets of wells for controls ( } 50 \text { wells each) }\end{array}$ & $\begin{array}{l}\text { Yes or no digital readout of } \\
\text { end-point fluorescence }\end{array}$ & 300 copies $/ \mathrm{mL}$ & mecA of Staphylococcus aureus & [71] \\
\hline
\end{tabular}

Table 2: Comparison between different RPA devices.

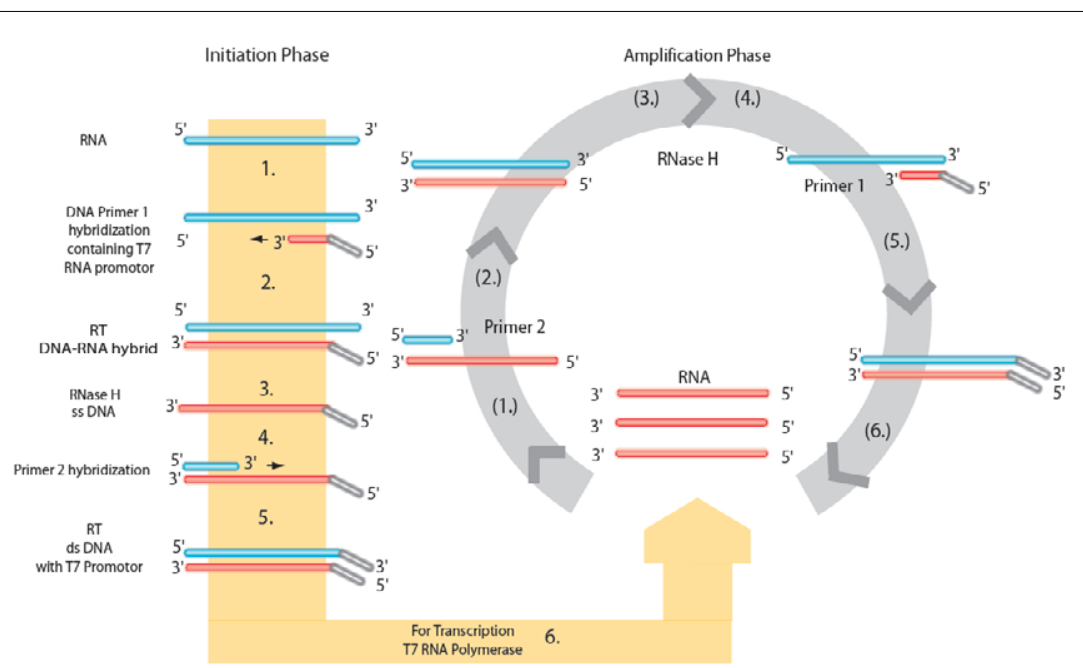

Figure 3: Schematic overview of the NASBA reaction. Initiation Phase: 1. DNA Primer anneals to RNA template; 2 . Primer extension by RT; 3. RNAse H eliminates RNA strand; 4 . Primer 2 annealing to DNA template; 5 . Polymerase activity of the RT elongates Primer 2, produces double stranded template DNA; 6. T7 RNA polymerase produces RNA transcripts. Amplification Phase steps (1.)-(6.) equal initial phase. 
amplification of a single strand within a time range of up to $90 \mathrm{~min}$ (Figure 3).

The reaction requires an initial heating step of $95^{\circ} \mathrm{C}$ (for DNA as template) resp. $65^{\circ} \mathrm{C}$ (for RNA) to prepare accessible single strands, before the amplification takes place at a constant temperature of $41^{\circ} \mathrm{C}$. During the initial phase, reverse DNA primers containing a T7 promoter region, bind to any available target sequence in the sample. The primers are extended by the reverse transcriptase (RT). The resulting RNA-cDNA hybrids are degraded by the activity of RNase $\mathrm{H}$, leading to cDNA single strands. A forward DNA primer hybridizes to these targets forming a new template which can be elongated by the reverse transcriptase. This step integrates the $\mathrm{T} 7$ promoter region into the produced DNA, allowing a T7 RNA polymerase to bind, generating complementary copies of RNA. During the cyclic process, each synthesized RNA will initiate a new round of duplication, leading to an exponential amplification which is comparable to the RT-PCR performance [76-78].

Shortly after the development of NASBA it was already applied for the fast detection and quantification of HIV-1 in patient blood samples [79]. Due to the direct use of RNA as well, this isothermal amplification method is optimal for RNA virus detection, viability tests of cells and transcriptional characterization.

For the quantification of RNA molecules, molecular beacons probes have shown potential to monitor the reaction in real-time [80-82]. During the reaction the fluorescence increases due to the sequence-specific annealing of the probes to their target strands. This process separates the fluorescence label from its neighbouring quencher (Figure 4).

The first integration of a NASBA reaction into a microfluidic
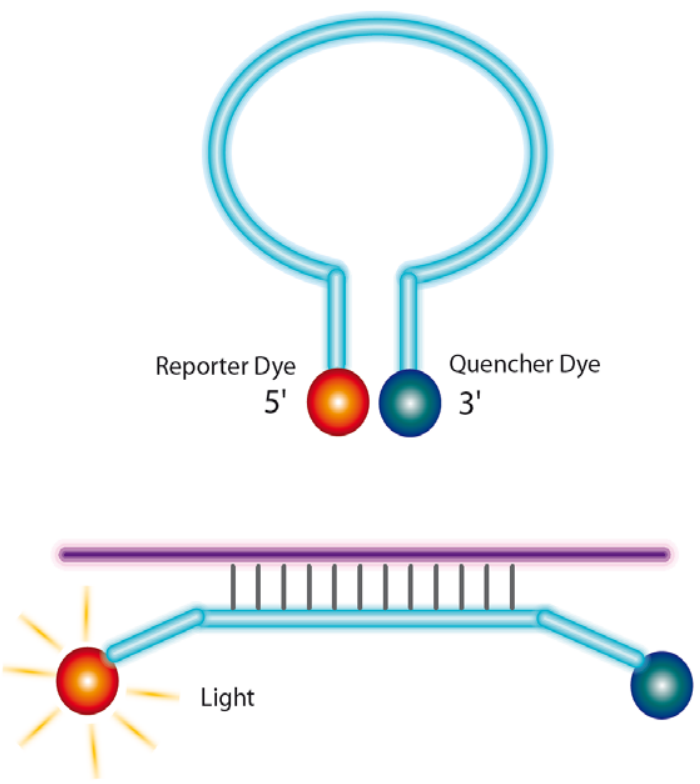

Figure 4: Molecular beacons as a common strategy to monitor the amplification process in real-time to quantify the initial concentration of target molecules. The beacons are forming a loop-structure, which opens in case of a hybridization event to a complementary strand. The stem formed of 4 to 6 bp keeps the molecular beacon 'closed' leading to a direct quenching of the fluorescence. silicon chip was shown in 2005 by Gulliksen et al. [83]. They have used the molecular beacon strategy to show sensitivities comparable to laboratory based NASBA reactions.

Zhao et al. [84] have reported a quantitative amplification microfluidic platform composed of a membrane-based sampling module, a sample preparation cassette, and a 24-channel Q-NASBA chip for environmental investigations on aquatic microorganisms. The multifunctional microfluidic system could detect a few microorganisms quantitatively and simultaneously. Also, they designed different aptamer- and immuno-NASBA assays, which can be used to monitor molecular profiling in serum samples [85] or detect waterborne pathogens [38].

McCalla et al. [86] tried to overcome amplification problems derived from the secondary structure of RNA by using a specific hybridization probe, which later serves as an easy accessible target. Different publications reported about the "sample-in, answer-out" diagnostic platforms, which integrate sample preparation, amplification using NASBA, and final detection [87]. To quantify and characterize human papilloma virus (HPV) successfully, they applied artificial and cervical smear samples and were able to measure up to 16 different targets simultaneously [87].

Instead of an optical detector, Nugen et al. showed the use of an integrated NASBA reaction to detect hsp70 mRNA from Cryptosporidium parvum by combining a low cost photolithographically produced electrochemical detector on a modified PMMA polymer substrate. The isothermal amplification enabled them to detect a single oocyst in a reaction volume of $4 \mu \mathrm{L}$ [88].

Esch et al. developed a microfluidic PDMS chip using NASBA for the detection of viable Cryptosporidium parvum [89]. Sandwich hybridization of the generated amplicons between capture probes and reporter probes, tagged with carboxyfluorescein-filled liposomes, enabled the detection. The limit of detection of this system was $5 \mathrm{fmol} / \mathrm{L}$ for a sample size of $12.5 \mu \mathrm{L}$.

By using the molecular beacon fluorescent probe technology, Dimov et al. presented an on-chip purification and quantitative amplification cDNA from E.coli cells [90]. They were able to detect $1000 \mathrm{cfu} / \mathrm{mL}$ in less than $3 \mathrm{~min}$ by using tmRNA as target sequence. tmRNA contains organism-specific sequences, has a higher stability compared to mRNA and has a high copy number per bacterial cell. The same group has shown sample processing of cells, their cultivation and different bioassays including gene expression analysis in the nanoliter range using NASBA [91].

Finally, Smith et al. were focussed on the development of a compact hand-held heated fluorometric device for performing a real-time NASBA. This battery driven system can support nucleic acid analysis in the field $[92,93]$.

Table 3 lists several platforms for NASBA in microsystems which were developed in the last eight years.

Multiplex NASBA was firstly shown in 1999 [94], but the lower efficacy in comparison to a singleplex reaction might be a reason for lacking publications of multiplex NASBA used in microsystems.

A general disadvantage of the NASBA reaction is the initial heating step to denature or to reduce secondary structure. A precise temperature control together with higher power consumption makes NASBA unfavourable, even though the actual reaction temperature $\left(41^{\circ} \mathrm{C}\right)$ is relatively low. However, a major advantage of the method 
Citation: Tröger V, Niemann K, Gärtig C, Kuhlmeier D (2015) Isothermal Amplification and Quantification of Nucleic Acids and its Use in Microsystems. J Nanomed Nanotechnol 6: 282. doi:10.4172/2157-7439.1000282

Page 7 of 19

\begin{tabular}{|c|c|c|c|c|}
\hline System design & Detection strategy & LOD & Target & Ref. \\
\hline $\begin{array}{l}\text { COC microchip }(50 \times 40 \mathrm{~mm}) ; 10 \text { parallel reaction channels; signals } \\
\text { can simultaneously detected in } 80 \mathrm{~nL} \text { volumes; custom-made optical } \\
\text { detection unit }\end{array}$ & Auto-fluorescence & $\begin{array}{l}10^{-6} \mu \mathrm{M} \\
20 \text { cells/ } / \mathrm{LL}\end{array}$ & $\begin{array}{l}\text { HPV } 16 \text { sequences } \\
\text { SiHa cell line }\end{array}$ & [83] \\
\hline $\begin{array}{l}\text { Q-NASBA microfluidic platform combines a membrane-based sampling } \\
\text { module, a sample preparation cassette, and a } 24 \text { channel Q-NASBA } \\
\text { chip }\end{array}$ & $\begin{array}{l}\text { Quantitatively by a common } \\
\text { microplate reader }\end{array}$ & $<10$ copies & $\begin{array}{l}\text { Saccharomyces cerevisiae; } \\
\text { E. coli; Staphylococcus aureus }\end{array}$ & [84] \\
\hline $\begin{array}{l}\text { Aptamer-NASBA chip modeled on a 384-well microplate; fabricated by } \\
\text { using MEMS technologies; bottom and cover layer: silicon wafer }\end{array}$ & $\begin{array}{l}\text { Quantitatively by a common } \\
\text { microplate reader }\end{array}$ & $2 \times 10^{-16} \mathrm{~mol} / \mathrm{L}$ & Gonadotropin (GnRH) & [85] \\
\hline $\begin{array}{l}\text { Reactor design contained } 11 \text { parallel channels with } 2 \text { separate chambers } \\
\text { (silicon-glass) for each heating step, separated by hydrophobic burst } \\
\text { valves; second chamber included dehydrated enzymes; full reaction } \\
\text { runs not on-chip; PDMS reactor for microfluidic separation }\end{array}$ & $\begin{array}{l}\text { Molecular beacon } \\
\text { fluorescence }\end{array}$ & Not specified & Influenza A/H5 vRNA & [86] \\
\hline $\begin{array}{l}\text { Automated LOC system for sample preparation, nucleic acid extraction, } \\
\text { amplification and real-time fluorescence detection: sample preparation } \\
\text { chip, NASBA chip ( } 75 \mathrm{~mm} \times 44 \mathrm{~mm} \times 1,5 \mathrm{~mm}) \text { consists of a disposable } \\
\text { microfluidic cartridge composed of injection moulded COC; NASBA } \\
\text { instrument }\end{array}$ & Real-time fluorescence & Not specified & HPV E6/E7 mRNA & [87] \\
\hline $\begin{array}{l}\text { Electrochemical biosensor based on a polymer substrate; channels } \\
\text { fabricated in PMMA using hot embossing with a copper master; } \\
\text { interdigitated ultramicroelectrode array (IDUA) realized directly on the } \\
\text { PMMA surface; } 2 \text { detection channels }\end{array}$ & Electrochemical & Not specified & $\begin{array}{l}\text { hsp70 mRNA from } \\
\text { Cryptosporidium parvum }\end{array}$ & [88] \\
\hline Microfluidic chip (PDMS) & $\begin{array}{l}\text { Real-time fluorescence by } \\
\text { using carboxy-fluorescein- } \\
\text { filled liposomes }\end{array}$ & $\begin{array}{l}5 \mathrm{fmol} \text { of } \\
\text { ampolicon in } \\
12.5 \mu \mathrm{L}\end{array}$ & Viable Cryptosporidium parvum & [89] \\
\hline $\begin{array}{l}\text { Integrated RNA purification chamber }(0.25 \mu \mathrm{L}) \text { and real-time NASBA } \\
\text { device }(2 \mu \mathrm{L}) \text {; channels and chambers: } 80 \mu \mathrm{m} \text { high }\end{array}$ & $\begin{array}{l}\text { Molecular beacon } \\
\text { fluorescent probe technology }\end{array}$ & $1000 \mathrm{CFU} / \mathrm{mL}$ & E. coli & [90] \\
\hline $\begin{array}{l}\text { Cellular and molecular analysis platform realized by an integrated } \\
\text { microfluidic array plate (iMAP) consists of } 64 \text { processing modules, that } \\
\text { can perfom } 64 \text { independent simultaneous integrated assays }\end{array}$ & $\begin{array}{l}\text { End-point fluorescence by } \\
\text { using a thermally controlled } \\
\text { inverted fluorescence } \\
\text { microscope }\end{array}$ & $100 \mathrm{CFU} / \mathrm{mL}$ & E. coli & [93] \\
\hline $\begin{array}{l}\text { Hand-held heated fluorometric instrument ( } 150 \mathrm{~mm} \times 48 \mathrm{~mm} \times 40 \mathrm{~mm} \text { ) } \\
\text { combines a Printed Circuit Board/Micro Electro Mechanical System } \\
\text { (PCB/MEMS) reaction detection/reaction chamber containing an } \\
\text { integrated resistive heater with attached miniature LED light source and } \\
\text { photo-detector and a disposable glass waveguide capillary to enable a } \\
\text { mini-fluorometer }\end{array}$ & & Not specified & Not specified & [92] \\
\hline
\end{tabular}

Table 3: Comparison between different NASBA devices.

is the production of single-stranded RNA molecules which can easily hybridize to fluorescently labelled probes without any necessary denaturation step. Though, the labile stability of RNA has to be considered, if the sampling-to-assay time is considerable. For pointof-care tests, where the diagnosis is close to the patient anyhow, the stability might be negligible.

Nowadays, some commercially available diagnostic products are based on real-time NASBA. BioMerieux (Marcy l'Etoile, France) is selling the NucleiSENSEasyQ system, which features the first automated system combining NASBA and real-time molecular beacon detection [95]. Up to 48 samples can be run in parallel with a detection of targets in less than 2 hours [96].

Coris BioConcept (Gembloux, Belgium) has also integrated NASBA in an oligochromatographic (OligoC) detection kit for Trypanosoma cruzi [97] and Leishmania spp. [98] in lateral flow format [99].

Furthermore TMA-based Kits are commercial available from GenProbe (San Diego, USA). Neiserria gonorrhoea, Chlamydia trachomatis, HPV, HIV, Trichomonas vaginalis and M. tuberculosis detection is available with this system $[100,101]$.

\section{HDA: Helicase-dependent amplification}

The helicase-dependent amplification, firstly described in 2004 [102], makes use of the naturally occurring process of DNA replication. A helicase unwinds the target DNA strand at a temperature of $37^{\circ} \mathrm{C}$ to circumvent the heat-induced denaturation step of PCR. The MutL protein stimulates the helicase unwinding, whilst the single-stranded binding (SSB) protein prevents re-hybridization of the separated ssDNA targets [103] (Figure 5). The primers can hybridize to the free ssDNA and a DNA polymerase subsequently extends them. This exponential reaction can produce million-fold copies of target DNA in 60 to $120 \mathrm{~min}$ [104]. The development of a heat-stable helicase from Thermoanaerobacter tengcongensis allowed driving the reaction at a temperature of $45^{\circ} \mathrm{C}$ to $65^{\circ} \mathrm{C}[103,105]$ without the addition of MutL and SSB. Furthermore the performance of the HDA was improved [104], leading to longer amplification fragments from initially up to $400 \mathrm{bp}$ to $>2000 \mathrm{bp}$ [104]. A sensitivity of as few as 10 copies of bacterial genomic DNA has been presented [103]. This thermophilic HDA system was further developed for diagnostic applications by Goldmeyer et al. $[106,107]$. They reported that the HDA is suitable for the rapid 


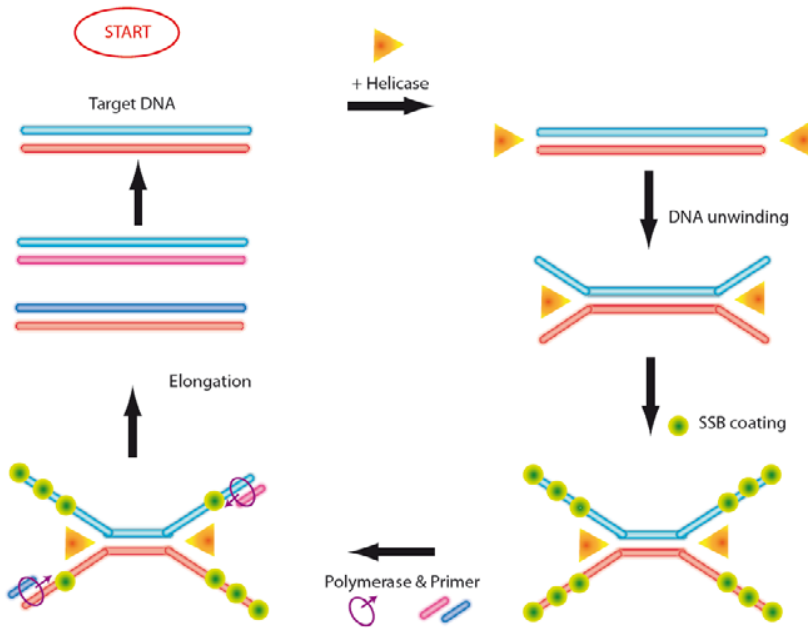

Figure 5: Schematic overview of the Helicase-dependent amplification.

characterization of Staphylococcus aureus and the determination of methicillin resistance by the detection of $m e c A$ gene.

The simple reaction scheme is one of the major advantages of HDA over other methods that often include more than one set of primers and just a singular enzyme [39]. There is no need for an initial denaturation step for DNA and the reaction has the ability to detect RNA [108-111]. HDA has been shown to be effective for various samples, from urine [112] and vaginal swabs [112] to blood [110,111] and stool $[108,109]$. Therefore, the HDA has a great potential for using it in portable pointof-care devices [113].

A study of Andresen et al. has shown a solid phase helicasedependent amplification using microarrays. One primer was immobilized to the surface of an epoxysilanized glass slide. The fluorescently-labelled second primer and the sample containing HDA enzymes were incubated for two hours to allow for bacterial pathogen monitoring [114]. The detection of Staphylococcus aureus from nasal swabs was presented in a study from Frech et al., were an asymmetric HDA was used to amplify specific sequences, which hybridized to capture probes on a DNA array. The readout was visible to the naked eye by an enzymatic process employing the dye Tetramethylbenzidine (TMB) [115].

A variety of different microfluidic devices was recently published, showing the attractiveness of an implemented HDA reaction. Ramalingam et al. have applied a PDMS-glass hybrid to integrate the amplification, but pre-purified the target DNA without integrating the process on the chip [116]. They built four parallel $5 \mu \mathrm{L}$ containing reaction chambers with pre-dried primers. The DNA sample was injected using a pipette and a real-time quantification of severe acute respiratory syndrome (SARS) coronavirus DNA was possible after $30 \mathrm{~min}$ reaction time. A detection of $0.1 \mu \mathrm{g} \mathrm{DNA} / \mathrm{mL}$ at a reaction temperature of $62^{\circ} \mathrm{C}$ for the HDA was demonstrated.

Mahalanabis et al. [117] describe the combination of a micro solid phase extraction ( $\mu \mathrm{SPE}$ ) for DNA isolation from whole bacteria and HDA in one disposable, flap-valve controlled thermoplastic cartridge (Figure 6). The $\mu \mathrm{SPE}$ column is used to lyse and extract DNA from whole bacteria in a liquid sample. The integrated process of detection of E. coli in broth medium was demonstrated in as little as $50 \mathrm{~min}$ at $65^{\circ} \mathrm{C}$ including all sample preparation steps.

Lately, the same group has demonstrated a low-cost device, which can be used for the detection of Clostridium difficile DNA in the stool of infected patients. A thermoplastic chip for the HDA was combined with commercially available toe warmers, which were able to keep the temperature stable at $65^{\circ} \mathrm{C} \pm 2^{\circ} \mathrm{C}$ for at least $55 \mathrm{~min}$. A similar limit of detection of $1.25 \times 10^{-2} \mathrm{pg}$ of $C$. difficile DNA was obtained compared to standard laboratory procedure [109].

Zhang et al. developed a droplet microfluidic system consisting of a PDMS chip including cell lysis, DNA extraction with superparamagnetic particles, and the HDA reaction visualized via fluorescence detection [118]. Here all reagents for analysis of pathogens or disease biomarkers are stored in small droplets, increasing the simplicity of this system.

A vertical-flow strip was also used by Tang et al. to amplify HIV1 gag gene (IsoAmp HIV-1 assay, BioHelix Corp., Veverly, MA) by a reverse transcription HDA [119]. The detection was done with a Type I BEST ${ }^{\mathrm{TM}}$ Cassette which is based on a sandwich immunoassay with capture probes (fluorescein isothiocyanate (FITC)-labelled) and detection probes (biotin-labelled). In $75 \%$ of these assays a positive result was shown for not more than 50 RNA copies.

An alternative to fluorescence detection was shown by Kivlehan et al. describing an electrochemical method for real-time detection with the possibility of quantification and melting curve analysis [120]. This method is based on a dsDNA intercalating redox probe that becomes less detectable upon binding. This decrease is measured by square-wave voltammetry (SWV) and compared to free counterparts.

Also Torres-Chavolla and Alocilja described an electrochemical method of HDA-amplicons using gold nanoparticles [121].

Table 4 displays several designs for the application of HDA which were developed in the last five years.

Already commercially available are standardized reagents and research kits from BioHelix (Beverly, MA, USA), the inventors of HDA. They offer tests for e.g. Staphylococcus aureus and MRSA, Clostridium difficile, HIV, Herpes Simplex, Chlamydia trachomatis and Neisseria gonorrhoeae based on their BESt ${ }^{\mathrm{TM}}$ Cassette [108,122-124].

\section{SDA: Strand Displacement Amplification}

The reaction, which can be performed over a broad temperature range $\left(37^{\circ} \mathrm{C}\right.$ to $\left.70^{\circ} \mathrm{C}\right)$, was already described in the early nineties applying multifunctional primers, both having target sequences for the

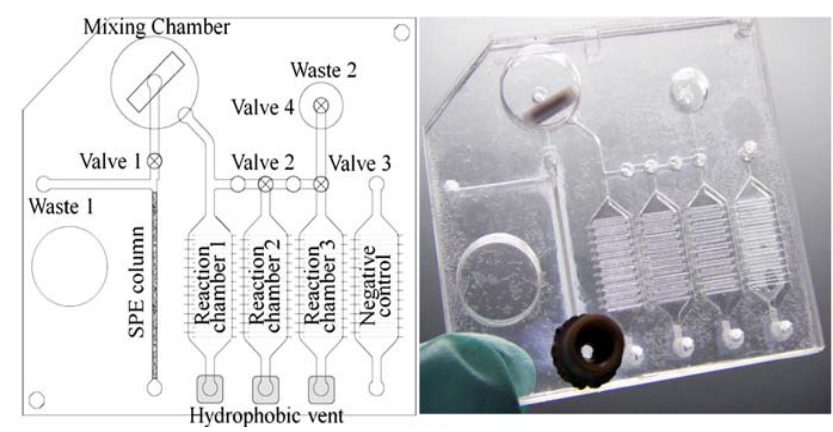

Figure 6: Left: Layout of the integrated disposable microfluidic device; a $\mu \mathrm{SPE}$ (solid-phase extraction) column, a flap valve, a hydrophobic vent and microchannels are integrated on a disposable cartridge format. Right Photograph of the fabricated device [117]. Reprinted with permission of Prof. Catherine Klapperich (University of Boston, USA). 
Citation: Tröger V, Niemann K, Gärtig C, Kuhlmeier D (2015) Isothermal Amplification and Quantification of Nucleic Acids and its Use in Microsystems. J Nanomed Nanotechnol 6: 282. doi:10.4172/2157-7439.1000282

Page 9 of 19

System design
OnChip-HDA amplification, or solid-phase amplification on a
microarray
T-structure poly-dimethylsiloxane (TSPS) coated wafer (aldehyde-
functionalized chip surface); poly (lys-phe) coated wafer (succimidyl-
4 -formyl benzoate (SFB) functionalized)
PDMS-glass hybrid; 4 parallel reaction chambers ( $5 \mathrm{LL}$ volume)
Disposable, flap-valve controlled thermoplastic cartridge; includes a
$\mu S P E$ column (COP; $0.55 \times 0.55 \times 20$ mm), flap valves, hydrophobic
vents, microchannels, 4 HDA reaction chambers (á $25 \mu \mathrm{L})$
Polymer-based microfluidic chip (COP) with multiple reaction
chambers (à $25 \mu \mathrm{L}$ ); toe warmer as heat source in a Styrofoam cup
Droplet microfluidic, sample-to-answer system (PDMS) including cell
lysis, DNA extraction with superparama-gnetic particles
Vertical-flow DNA detection strip
Screen printed carbon electrode (SPCE) chip; dextrin coated gold
nanoparticles as electrochemical reporter

Detection strategy
Real-time fluorescence
Naked eye by an enzyma
process employing the dy
Tetramethylbenzi-dine (TM
Real-time fluorescence
Real-time fluorescence
Real-time fluorescence
Real-time fluorescence
Visual detection
Electrochemical

\begin{tabular}{|c|c|c|}
\hline LOD & Target & Ref. \\
\hline $\begin{array}{l}1 \mathrm{ng} \\
250 \mathrm{pg}\end{array}$ & $\begin{array}{l}\text { Neisseria gonorrhea; } \\
\text { Staphylococcus aureus }\end{array}$ & [114] \\
\hline $\begin{array}{l}\leq 2 \text { CFU per } \\
\text { swab }\end{array}$ & nuc of Staphylococcus aureus & [115] \\
\hline $\begin{array}{l}0,1 \mu \mathrm{g} \mathrm{DNA} / \mathrm{mL} \\
\leq 10 \mathrm{CFU}\end{array}$ & $\begin{array}{l}\text { Severe acute respiratory } \\
\text { syndrome (SARS) DNA } \\
\text { E. coli }\end{array}$ & $\begin{array}{l}{[116]} \\
{[117]}\end{array}$ \\
\hline $1.25 \times 10^{-2} \mathrm{pg}$ & Clostridium difficile DNA & [109] \\
\hline Not specified & $\begin{array}{l}\text { Ovarian cancer biomarker Rsf-1; } \\
\text { E. coli }\end{array}$ & [118] \\
\hline 50 copies & HIV-1 gag gene & [119] \\
\hline $0.01 \mathrm{ng} / \mu \mathrm{L}$ & IS6110 gene of. M. tuberculosis & [121] \\
\hline
\end{tabular}

Table 4: Comparison between different HDA devices.

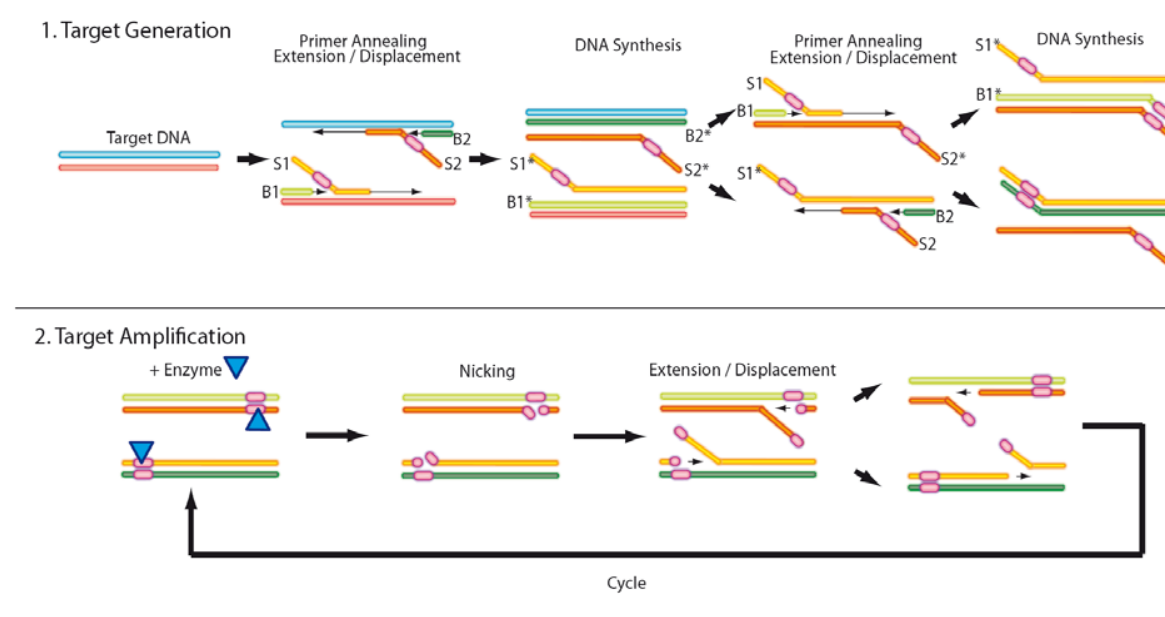

Figure 7: Scheme of the Strand displacement amplification.

directed hybridization to the DNA strand of interest and a restriction site for endonucleases [125,126] (Figure 7).

After the heat induced strand separation of the dsDNA, the primers bind sequence-specifically introducing a restriction site into the product. Bumper primers, which bind adjacent to the first primer, will be elongated by a polymerase with strand displacement activity, releasing the first single-stranded amplicon. In a second step, the reverse primer - also with an included nickable restriction site, will be elongated (Figure 7). An endonuclease will cleave the restriction sites only at one strand, because thiol-modified nucleotides are incorporated to prevent cutting of the whole ds DNA strand. The free 3 '-end is subsequently extended, displacing the new single stranded copy molecule. This process of nicking and displacing will lead to an exponential amplification of DNA.

However, SDA is not a common method for point-of-care or microfluidic devices [38]. The need of an initial denaturation step and a longer processing time of two hours may be a reason. Additionally, some reports have shown a co-amplified background signal due to unspecific primer binding $[125,127]$. Due to the excess of human DNA in clinical samples [128,129], the large background nucleic acid can hamper the efficiency of the SDA considerably.

Another major disadvantage is the limited use of suitable restriction enzymes. A recognition sequence of about 5 bp occurs on average every 1024 nucleotides, thus templates longer than 1000 nts cannot be used. Furthermore thiol-modified nucleotides might influence downstream applications [130].

Nonetheless, the integration of the SDA on lateral flow strips was demonstrated by $\mathrm{He}$ et al. They combined the isothermal amplification of a human gene with a visual, gold-nanoparticle-based detection of a mutation within the keratin 10 gene [131]. A detection limit of $1 \mathrm{fM}$ of the R156H-mutant DNA within 75 min without the use of any instrumentation was shown. Already in 1998, an integration of the reaction on a glass-silicon hybrid was demonstrated by Burns et al. A 106-bp DNA fragment was amplified in the nanoliter range and 
elctrophorectically analyzed in only $17 \mathrm{~min}$ [132]. Precise metering of reaction mixtures was done by using hydrophobic patches and an air-pressure source. Volumes below $1 \mathrm{~nL}$ can be separated and moved within the channels. In 2002, Nanogen, Inc. presented the integration of a SDA module into an electric-field-driven DNA hybridization assay. The identification of the Shiga-like toxin gene from E. coli was accomplished within $2.5 \mathrm{~h}$ starting from a dielectrophoretic concentration of intact $E$. coli bacteria and finishing with an electricfield-driven DNA hybridization assay, detected by fluorescently labelled DNA reporter probes [133].

A multiplex SDA for up to ten targets was shown by Westin et al. in a microarray chip with anchored primers [134].

Table 5 lists different strategies for the application of SDA in microsystems.

The SDA is commercialized by Becton Dickinson since 1999. The BD Probe $\mathrm{Tec}^{\mathrm{TM}}$ ET System enables the user to characterize and quantify in real-time of up to 564 samples in eight hours [135]. Its usefulness has been shown in clinical setups especially for the detection of Chlamydia trachomatis and Neisseria gonorrhoeae and other pathogens [136141]. The technology is utilized to generate billions of copies of target molecules from a single DNA or RNA template in the one-hour assay time [142]. The high throughput platform is FDA cleared/CE marked and supports tests for HSV from urogenital samples as well. The quantitative detection can be done by using the molecular beacon technique [135].

\section{RCA: Rolling circle amplification}

RCA, first described 1998 [143,144], exploits the excellent strand displacement activity of a Phi29 bacteriophage polymerase on target molecules. The isothermal reaction allows for the amplification of a single-stranded DNA to generate a continuous catenated product of up to 0.5 Mbases. Different approaches to perform the reaction have been reported [145-147], whereas the here described padlock probes have been used very successfully for linear DNA. These probes are linear oligonucleotides containing two target specific sequences, which are designed to circularize after hybridization and subsequent ligation (Figure 8). The dual recognition in combination with a ligation reaction ensures specificity of detection. After that, the circular padlock probe serves as template for the polymerase, which continuously elongates the product and displaces the generated strand [35]. It is also possible to use further primers binding the generated product and thereby producing hyper branching structures. This reaction then is called ramification amplification and was described 2001 by Zhang et al. [148].

Optimized RCA was able to detect $0.163 \mathrm{pg}$ ( 60 molecules) of genomic DNA from Listeria monocytogenes [149], or $143 \mathrm{zmol}(8.6 \mathrm{x}$ $10^{4}$ molecules) of in vitro transcribed human CD4 mRNA [150].

Sato et al. described a solid phase RCA for the on-chip detection of Salmonella enterica sequences from samples within [34]. Figure 9 shows the capture and ligation of a specific target DNA at $55^{\circ} \mathrm{C}$. A circular primer is pre-hybridized to the $34 \mu \mathrm{m}$-capture bead. After a ligation step, the linear strand is produced by RCA. To finally quantify the product, a fluorescent probe was hybridized to the amplicon.

Mahmoudian et al. reported about combining circle-to-circle amplification (C2CA), a variant of RCA, with microchips using an electrophoretic port as a RCA reaction chamber. $25 \mathrm{ng}$ of bacterial genomic DNA was detected in less than 65 min (including RCA and PMMA-based microchip electrophoresis) [151,152].

MicroRNAs (miRNAs) are non-coding small RNAs which play a central role in cellular regulation [153]. Providing the necessary sensitivity for the detection of miRNA in single cells, Wu et al. introduced a flow cytometry-on-a-chip device to detect the presence and localize the miRNA. A combination of rolling circle amplification and locked-nucleic acid probes allowed for the characterization of relative miRNA changes at a single cell resolution. The approach makes use of a 10-chamber microfluidic chip platform and a small amount of only 170 $\mathrm{nL}$ of reagent per single experiment. Konry et al. have demonstrated a similar droplet-based microfluidic device which enabled the user to detect protein markers in a nanoliter reaction volume. After highly specific antigen-antibody recognition, a combined RCA allowed the visual fluorescence detection of less than ten EpCAM surface tumor markers per cell [154].

The integration of RCA for a completely different strategy was shown by Zhao et al. [155]. The group demonstrated the coating of a microfluidic surface by using rolling circle amplification. The resulting 3D DNA network extends over tens of micrometer into the solution comprising of repeating adhesive aptamer domains. These structures were able to bind the protein tyrosine kinase-7 (PTK7) which is overexpressed on many human cancer cells [155]. The work impressively demonstrated the capture of target cells from biological sample by mimicking the strategies of marine organisms.

A similar technique was reported by Barbee et al., who fabricated DNA polymer brush arrays on a solid glass support. Oligonucleotides were covalently immobilized, a spin-coated photoresist covered the

\begin{tabular}{|c|c|c|c|c|}
\hline System design & Detection strategy & LOD & Target & Ref. \\
\hline Lateral flow strip through dual immunoreactions & $\begin{array}{l}\text { Lateral flow dipstick; } \\
\text { visual detection }\end{array}$ & $<1 \mathrm{fM}$ & $\begin{array}{l}\text { R156H-mutant gene of keratin } 10 \\
\text { in Epiderm-olytic hyperkeratosis }\end{array}$ & [131] \\
\hline $\begin{array}{l}\text { Glass-silicon hybrid includes a nanoliter liquid injector, a sample mixing, } \\
\text { a positioning system, a tempe-rature-controlled reaction chamber, an } \\
\text { electrophoretic separation system, and a fluorescence detector }\end{array}$ & Electrophoretical & Not specified & Not specified & [132] \\
\hline $\begin{array}{l}\text { Integrated, stacked microlaboratory; fabricated by orderly laminating } \\
\left.\text { several different functional layers (all } 76 \times 76 \mathrm{~mm}^{2}\right) \text {; SDA module }(76 \\
\times 298.5 \mathrm{~mm}^{2} \text { ) consists of a denaturation chamber, an amplification } \\
\text { chamber, two pinch, two peristaltic pumps, and an electronic control } \\
\text { circuit for fluidic and thermal control }\end{array}$ & $\begin{array}{l}\text { Electric-field-driven } \\
\text { immunoassay }\end{array}$ & Not specified & $\begin{array}{l}\text { Shiga-like toxin gene (SLT1) from } \\
\text { E. coli }\end{array}$ & [133] \\
\hline $\begin{array}{l}\text { Microchip array; electronic anchoring of sets of amplification primers in } \\
\text { distinct areas }\end{array}$ & $\begin{array}{l}\text { Fluorescence-based by an } \\
\text { electronic hybridization assay }\end{array}$ & Not specified & $\begin{array}{l}\text { Chlamydia; E. coli parC; } \\
\text { Pseudomonas; Salmonella; E. coli } \\
\text { gyrA }\end{array}$ & [134] \\
\hline
\end{tabular}

Table 5: Comparison between different SDA devices. 


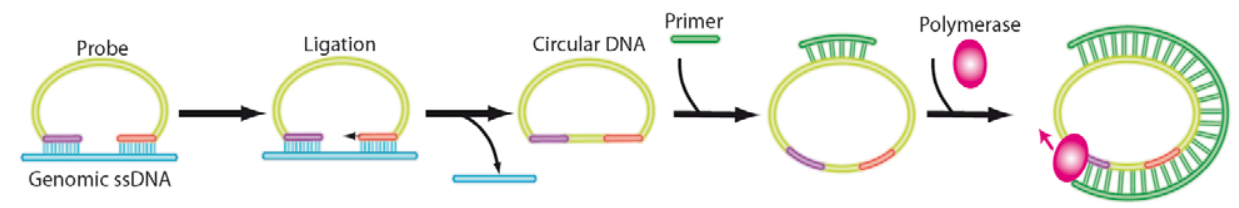

Figure 8: Rolling circle amplification. The padlock probe, one of various different strategies to use this isothermal amplification technique, hybridizes sequence specifically to the target strand.

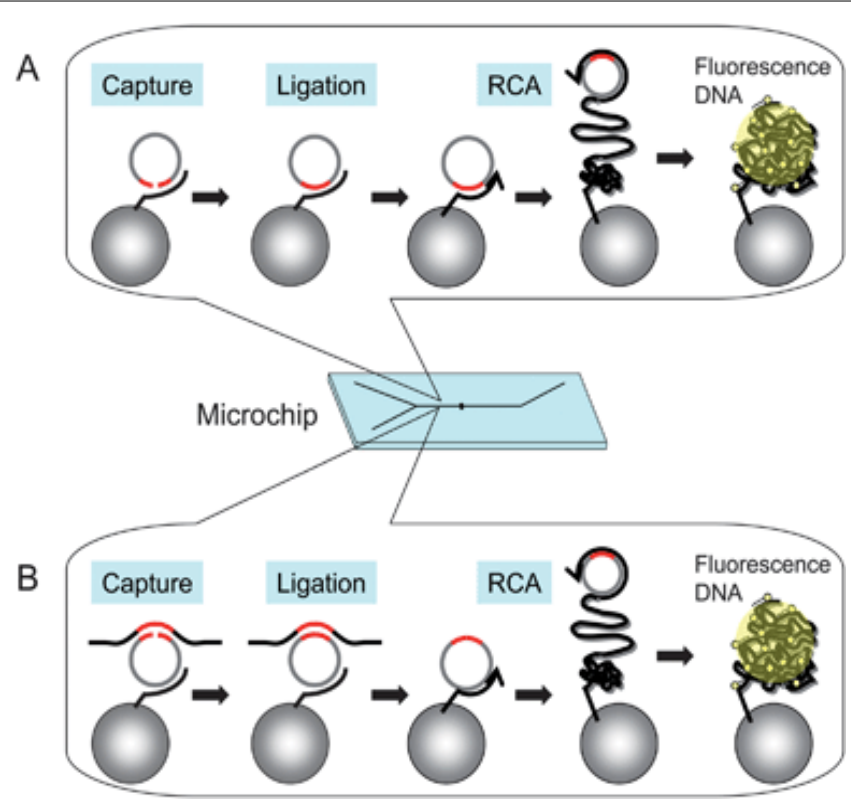

Figure 9: Schematic overview of the microchip-based RCA. A: Model experiments using a padlock probe as a sample for RCA; B: Experiments to test the detection of a Salmonella DNA fragment [34]. Reproduced from Ref. 34 with permission from The Royal Society of Chemistry.

DNA and oxygen-based plasma was used to destroy the exposed oligonucleotide primers. After assembly into a microfluidic chip, the DNA brushes were synthesized on the oligonucleotide array by rollingcircle DNA amplification. Barbee discussed various applications for these arrays [156].

Another unusual application for RCA on microfluidics was lately described by Juul et al. [157]. Microfluidics fabricated by conventional PDMS-based soft lithography techniques and channel heights at 25 $\mu \mathrm{m}$ was used to study enzymatic activities down to the single cell level. A picoliter droplet-based approach separated the sample solution, whereas the RCA was used to monitor the functionality of recombinase or topoisomerase-like proteins. The latter support the linkage of a circular probe, which can serve as a template for the RCA.

Protein detection was shown by Yan et al., who capture target molecules, carcinoembryonic antigen (CEA), a clinically important tumour marker, from biological samples by using magnetic particles. A second antibody immobilized to a gold nanoparticle, which is covered with primers for RCA enabled the single amplification by integration of biotinylated dNTPs. Latter were bound by avidin-HRP conjugates resulting in an observable coloured product [158]. The use of RCA on protein microarrays to increase the efficiency of Raman detection was demonstrated by the same group. Less than 10 zeptomol of protein molecules were detectable by using the isothermal amplification method for signal enhancement [159].

Various other readout systems for RCA are nicely described in Stougaard et al. [160].

Mazutis et al. described a droplet-based microfluidic system for single molecule amplification by RCA [161]. Quantification was done by analyzing an intercalating fluorochrome. The $2 \mathrm{pL}$ sample droplets were fused with a $15 \mathrm{pL}$ droplet consisting of an in vitro translation system and a fluorescein-di- $\beta$-D-galactopyranoside (FDG). During the formation of fluorescein $\beta$-galactosidase from FDG the enzyme activity can be measured by fluorescence detection.

In a sandwich capture assay streptavidin-coated magnetic beads are immobilized to biotinylated virus capture DNA. This capture DNA then binds reporter and viral target DNA through incubation. By adding the RCA buffer the target and the reporter DNA is released into a single well and RCA can be accomplished, whereby the reporter DNA is extended and detected by real-time fluorescence measurement [162]. Also Li et al. used streptavidin coated magnetic beads for DNA isolation by annealing of a biotin labelled capture probe to the target DNA [118]. Here a padlock probe is used as well as additional primers for ramification amplification (RAM).

A multiplex RCA assay is shown by Nallur et al. using primers anchored on surface, in a microarray [163]. Detection was done by fluorescence labelled probe and laser scanning. Also quantification was accomplished with the help of quantification software.

Table 6 presents diverse platforms for the application of RCA which were developed in the last five years.

GE Healthcare \& Life Science (Piscataway, USA) for example made rolling circle amplification commercially available and sell it under the brand name illustra TempliPhi 100 Amplification Kit.

\section{SMART: Signal-mediated amplification of RNA technology}

SMART is an isothermal amplification technology, developed for the detection of specific target sequences, either RNA (for expression) or DNA [164]. The SMART assay consists of two single stranded oligonucleotide probes ("extension" and "template"), which both can hybridize abreast to the target strand (Figure 10). One part of each primer can hybridize to each other to form a three-way junction (3WJ). After the three-way junction formation, a DNA polymerase elongates the shorter extension probe, meanwhile synthesising the complementary strand of the template probe, which includes a T7 RNA polymerase promotor sequence. Subsequently, the transcription template with the promotor sequence will be produced, allowing for a multiplicative production of transcription RNAs by a T7 RNA polymerase. It is also possible to increase the yield and make this reaction more sensitive by binding another probe with a T7 RNA polymerase promoter sequence 
Citation: Tröger V, Niemann K, Gärtig C, Kuhlmeier D (2015) Isothermal Amplification and Quantification of Nucleic Acids and its Use in Microsystems. J Nanomed Nanotechnol 6: 282. doi:10.4172/2157-7439.1000282

Page 12 of 19

\begin{tabular}{|c|c|c|c|c|}
\hline System design & Detection strategy & LOD & Target & Ref. \\
\hline $\begin{array}{l}\text { Glass microchip; Y-shapes channels with a dam structure for } \\
\text { bead retention; Peltier temperature controller to control the } \\
\text { temperature }\end{array}$ & $\begin{array}{l}\text { Fluorescence and phase-contrast } \\
\text { images }\end{array}$ & $88 \mathrm{ng}$ & Salmonella enterica sequences & {$[34]$} \\
\hline $\begin{array}{l}\text { PMMA microchip; on-chip detection by using a polymer separation } \\
\text { matrix and fluorescence dye }\end{array}$ & Electrophoretic & $25 \mathrm{ng}$ & Bacterial genomic DNA & {$[151,152]$} \\
\hline $\begin{array}{l}\text { Ten-chamber microfluidic chip; fluidically-isolatable chambers (up } \\
\text { to } 2000 \text { cells); }\end{array}$ & Fluorescence image; flow cytometry & Not specified & miR155 and CD69 & [153] \\
\hline Droplet-based microfluidic device (PDMS) & Visual fluorescence & $\begin{array}{l}<10 \text { molecules/ } \\
\text { cell }\end{array}$ & EpCAM surface tumor markers & [154] \\
\hline $\begin{array}{l}\text { Microfluidic device to capture and isolate cells using a 3D DNA } \\
\text { network comprising repeating adhesive aptamer domains that } \\
\text { extend over } 10 \mu \mathrm{m} \text { into the solution }\end{array}$ & Fluorescence image & Not specified & Minimal residual disease (MRD) & [155] \\
\hline $\begin{array}{l}\text { DNA polymer brush arrays; fabricated on glass coverslips using } \\
\text { a destructive micropatterning technique and solid-phase RCA; } \\
\text { additional microfluidic device with temperature control }\end{array}$ & $\begin{array}{l}\text { Fluorescence image; gel } \\
\text { electrophoresis; atomic force } \\
\text { microscopy }\end{array}$ & Not specified & Not specified & [156] \\
\hline $\begin{array}{l}\text { Flow focusing droplet generator and a droptrap; channel height: } \\
25 \mu \mathrm{m}\end{array}$ & Fluorescence image & Few cells & Topl, Flp, and Cre & [157] \\
\hline $\begin{array}{l}\text { Droplet-based microfluidic system (PDMS) for generation } \\
\text { spheroids and their separation }\end{array}$ & $\begin{array}{l}\text { Real-time fluorescence; cytotoxicity } \\
\text { test }\end{array}$ & Not specified & HeLa; HEK293 & [161] \\
\hline $\begin{array}{l}\text { Microarrays printed on streptavidin-coated glass microscope } \\
\text { slides }\end{array}$ & Laser scanning and image analysis & $\leq 150$ molecules & Not specified & [163] \\
\hline
\end{tabular}

Table 6: Comparison between different RCA devices.
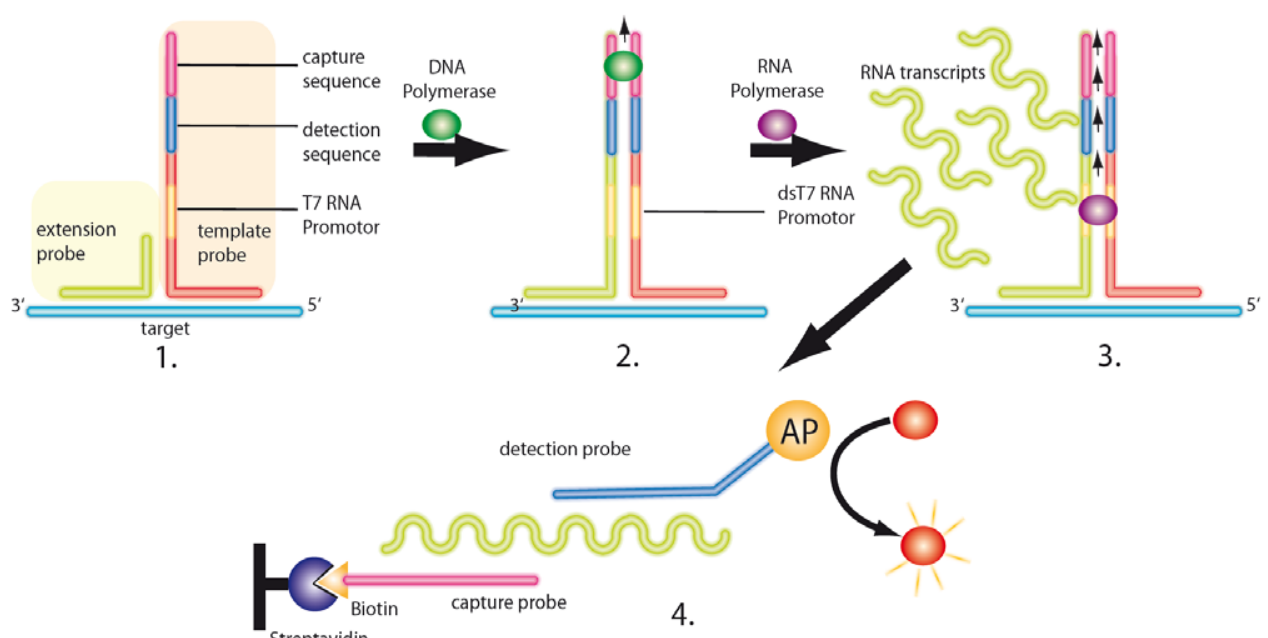

3.

to the amplified RNAs [164].

The detection of RNA can be done efficiently in approx. $1 \mathrm{~h}$ at $41^{\circ} \mathrm{C}$, whereas the detection of DNA still needs an initial denaturation step of $>90^{\circ} \mathrm{C}$ [165]. To further increase the sensitivity, Hall et al. [165] described an enzyme-linked oligosorbent assay. Alternatively, the amplified RNA complex is captured on magnetic beads using a sequence-specific capture probe and is separated from unbound probe using microfluidics [86]. A rapid detection of $100 \mathrm{fmol} / \mathrm{L}$ from an artificial influenza A H5 vRNA sequence requiring only $5 \mu \mathrm{L}$ of reaction volume has been demonstrated. Morabito et al. have presented the detection of a HIV-1 reverse transcriptase drug-resistance mutation, which was partly done on a microfluidic platform in less than $180 \mathrm{~min}$ [81].

For the quantification of the reaction, molecular beacon approach has been applied successfully $[81,86]$.

Table 7 lists several strategies for the application of SMART which were developed in the last three years.

\section{Various other methods}

Whole genome amplification by isothermal methods was reported lately by $\mathrm{Li}$ et al. [166]. The so called primase-based whole genome 


\begin{tabular}{|c|c|c|c|c|}
\hline System design & Detection strategy & LOD & Target & Ref. \\
\hline Microfluidic reactor with 4 channels (PDMS) & Real time fluorescence & Not specified & Influenza A H5 vRNA & [86] \\
\hline $\begin{array}{l}\text { Microchip reservoirs; simple 4-channel device, in which each channel } \\
\text { is tapered and designed for adequate separation of conjugated } \\
\text { magnetic beads from unbound SMART probes using a magnetic bar }\end{array}$ & $\begin{array}{l}\text { Gel electrophoresis; } \\
\text { real-time fluorescence }\end{array}$ & Not specified & $\begin{array}{l}\text { K103N (HIV-1 reverse transcriptase } \\
\text { drug-resistance mutation) }\end{array}$ & [81] \\
\hline
\end{tabular}

Table 7: Comparison between different SMART devices.

amplification (pWGA) method from Harvard University has shown promising results in case when total DNA needs to be amplified (e.g. DNA archiving, single cell analysis, tracing of DNA contaminations, or forensics). The method employs the functionality of a DNA primase, which synthesizes primers in vitro. No need of added primers, no thermocycling nor prior heat-denaturation make that principle very promising for the transfer into microfluidic devices. The reaction has initially shown an over thousand-fold amplification after $1 \mathrm{~h}$ at $37^{\circ} \mathrm{C}$ [166]. By using circular DNA as template, a $10^{8}$ fold amplification of as low as 100 initial target strands has been achieved. In addition to amplifying total genomic DNA, pWGA can also be used for detection and quantification of contaminant DNA in a sample when combined with a fluorescent reporter dye [166]. The commercialization is covered by BioHelix (Beverly, MA, USA).

The Japanese RIKEN Institute has developed the SmartAmp or Smart Amplification Process version 2 (SMAP2), which is based on selfpriming, loop-forming motifs similar to the LAMP process. It allows a rapid detection in 15 to $30 \mathrm{~min}$ at with a complete suppression of disturbing background $[167,168]$. To further improve the specificity of the reaction and to suppress the background signal, the mutation binding protein MutS is employed [169]. MutS, which is a part of the naturally occurring mismatch repair system, identifies mismatched target strands or primers. The amplification is processed by the strand-displacing Alicyclobacillus acidocaldarius polymerase. If a MutS protein detects a mismatched duplex, it binds irreversibly to that position and blocks any further amplification. Non-specific sequences result therefore in an inhibition of amplification resp. product development. A variety of different SNP detection methods have lately been described [169-171]. Kawai et al. report about a first Influenza A (H1N1) assay, combining both a reverse transcriptase and a SmartAmp amplification in one-step setup. After a simple gel-filtration step of the swap sample, the reaction time was $40 \mathrm{~min}$ to result [172]. Monitoring of the amplification is easily possible by using dsDNA intercalating fluorescent dyes. The SmartAmp or SWAP2 has demonstrated an excellent specificity and sensitivity ( 3 copies), but is slower in comparison to LAMP $[38,169]$. However, due to its advantages including the reduction of background effects, the reaction might be very useful for integrated microsystems in future. The Japanese company DNAFORM will offer kits for SMAP2 soon, whereas the RIKEN institute supports the potential users with an online tool for primer design (http://smap.gsc.riken.jp/smap/ PrimerDesign.do).

Jung et al. described another unique isothermal target and signaling probe amplification method, called iTPA, in combination with a facile gold nanoparticle (AuNP)-mediated colorimetric method for real-time detection of target DNA [173]. The iTPA simultaneously amplifies the target and signaling probe through two displacement events under isothermal conditions. Due to this method, as low as $10^{2}$ copies of target Chlamydia trachomatis plasmid were successfully detected in a colorimetric manner. The strategy does not require a thermo-cycler or other devices and is remarkable simple and convenient. Therefore, this approach is a promising application in portable sensor systems such as microfluidic devices or POCT diagnostic.

A rapid on-site detection of Acidovorax citrulli by cross-priming amplification (CPA) was presented by Zang et al. [174]. The CPA is an isothermal DNA amplification method developed by Ustar Biotechnologies Co., Ltd., China. It belongs to a class of isothermal amplification reactions that is realized by a strand displacement DNA polymerase and does not require an initial denaturation step or the addition of a nicking enzyme [175]. The detection of resulting amplicons is visualized on a lateral flow strip housed in an enclosed, sealed plastic device in order to prevent the leaking of products. The sensitivity of CPA for pure culture was $3.7 \times 10^{3} \mathrm{CFU} / \mathrm{mL}$. Consequently, it is a valuable alternative to immunoassays and PCR-based tests for diagnosis of A. citrulli.

Recently, aptamer-based analytical methods have been developed for protein detection. Ma et al. elaborated a cascade signal amplification strategy based on molecular switches and aptamers to improve protein detection [176]. This strategy consisted of two steps, including the recognition and the triggering of a polymerase reaction. The approach was constructed to simplify the analysis by detecting trace amounts of target isothermally, in real-time, and in a homogeneous solution. Ma and co-workers applied this method to measure thrombin in human serum samples and determined detection at a concentration as low as $0.17 \mathrm{nmol} / \mathrm{L}$ thrombin within 60 minutes.

An isothermal reaction for simultaneous amplification and detection of DNA is the beacon assisted detection amplification (BAD AMP). Connolly and Trau designed an integrated "biological circuit" composed of two molecular switches to detect, amplify and measure a specific DNA sequence in a cellular extract [177].

In 2003, Van et al. developed an exponential amplification reaction (EXPAR) for short oligonucleotides (called triggers) combining polymerase strand extension and single-strand nicking [178]. The reaction yields the $10^{6}$ to $10^{9}$-fold DNA amount under isothermal conditions within minutes. Jia and co-workers demonstrated that the EXPAR method is particularly suitable for the efficient amplification of small miRNAs [179]. By real-time measurement of fluorescence intensity, the presence of as low as $0.1 \mathrm{zmol}$ of a miRNA ( less than 100 copies of miRNA molecule in a volume of $10 \mathrm{~mL}$ ) can be exactly defined. The assay displayed a great dynamic range over 10 orders of magnitude and high specificity to clearly discriminate a one-base difference in miRNA sequences. Furthermore, this method can be performed by using SYBR Green I as a fluorescent dye. Consequently, it is a simple, low-cost and highly sensitive method that should contribute significantly to future advances in research on the biological roles of miRNAs as applications in clinical diagnostics with miRNA as target. Nicking enzyme amplification reaction (NEAR) is a recent improvement of EXPAR, because it allows the any target amplification by inserting nicking enzyme recognition sites inside of the targeted gene sequence [178]. The NEAR technology is based on the very fast detection of small DNA or RNA fragments generated directly from the target nucleic acid. One main target of the proposed NEARs is 
therefore small microRNAs [179], which can be amplified by $>10^{6}$ fold within minutes [178]. A combination of different isothermal amplification methods for the detection of microRNA has given a limit

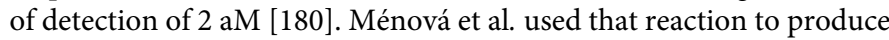
short diverse base-modified single-stranded oligonucleotides that are of potential interest as labelled primers or functionalized aptamers $[181,182]$. Although there are still not many publications on NEAR, two companies are very active in developing assays based on NEAR. Ionian Technologies Inc. (San Diego, USA) founded by the inventor of the technology, is currently focused on diagnostic products. They demonstrated the detection of Neisseria gonorrhoeae and Chlamydia trachomatis in 5 min with a LOD of 10 copies [38]. EnvirLogix Inc. (Portland, USA) have shown the use of NEAR for the point-of-testing of plant pathogens [183]. The amplification products can be detected by a variety of standard methods, including LC-MS, real-time fluorescence, and capillary electrophoresis detection.

In addition to NEAR, the nicking enzyme mediated amplification (NEMA) is a similar reaction that was developed in 2006 from You et al. (Hagzhou Yousida Biotechnology Co. Ltd.) [184]. Both NEAR and NEMA use nicking enzymes instead of restriction enzymes, so there is no need for modified nucleotides like it is in the SDA reaction. The difference between both reactions is the application of only inner primer pairs in NEAR, while NEMA needs two primer pairs like in the SDA reaction [185].

The isothermal and chimeric primer-initiated amplification of nucleic acids (ICAN) was developed by Takara Bio Inc. and amplifies DNA targets by employing Rnase $\mathrm{H}$ and a strand displacing polymerase [186-188] at $55^{\circ} \mathrm{C}$ after an initial denaturation step. This method uses a single pair of 5'-DNA-RNA-3' chimeric primers and has given a signal at $100 \mathrm{fg}$ resp. a few hundred copies of template DNA [186]. Practical work in the area of diagnostics was done on the amplification of $16 \mathrm{~S}$ rDNA [189] or semi-automated bacterial spore detection systems for bio-warfare agents (e.g., Bacillus anthracis) including an aerosol sampler [190]. The detection of $10^{4}$ spores was achieved within $2 \mathrm{~h}$ employing microfluidics. Quantification of targets was possible by measuring an increase of fluorescence. Commercial kits are available from Takara Bio (Otsu, Japan), e.g. gene polymorphism typing systems.

Isothermal chain amplification (ICA) was developed by RapleGene Inc. in 2010. A DNA-RNA-DNA chimeric primer set and a further outer primer set for strand displacement are used. RNase $\mathrm{H}$ cuts the RNA, anneals to the single strand and a strand-displacing polymerase generates the amplicon [191].

The single primer isothermal amplification (SPIA) was developed by $\mathrm{NuGen}^{\mathrm{TM}}$ in 2005, which provide various SPIA products [192]. This reaction uses a chimeric primer consisting of DNA at the 3 '-end and RNA at the 5 '-end. After the primer annealing and the elongation by a DNA polymerase the RNA at the $5^{\prime}$-end is cleaved by RNase $\mathrm{H}$ and the strand displacement activity of the polymerase displaces the synthesized stand by elongation of the new annealed primer. This reaction is done by $45-50^{\circ} \mathrm{C}$ for approximately $4 \mathrm{~h}$. RNA as well as DNA can serve as amplification target [39]. Integration into a point-of-care system has not yet been shown.

Dirks and Pierce described in 2004 the hybridization chain reaction (HCR) for linear amplification of DNA without the need of enzymes. Two stable DNA hairpins are opened in the presence of the target DNA. These leads in a cascade of hybridization events to a growing DNA chain, that can be detected [193].

\section{Conclusion}

In this study, we highlighted the best known isothermal amplification methods for nucleic acids in combination with miniaturized systems. Several different solutions for microfluidic devices capable for particulary LAMP, RPA, NASBA, HDA, SDA, RCA and SMART were demonstrated.

The benefit of isothermal amplification methods compared to PCR is the constant temperature of amplification. This will result in a high potential for a simple integration in point-of-care devices and a reduction of complexity.

Microfluidic-based systems for isothermal amplification of nucleic acids have generally many advantages to the user, including lower costs, minimum consumption of samples, faster analysis and automation of all steps from sample preparation to signal detection. In comparison to PCR, there is no need for a sophisticated heating and cooling device, which controls the temperature cycles accurately. However, some isothermal reactions need a precise temperature control as well. In order to achieve an optimal and efficient heat transfer into the reaction chamber, the contact of the heating source to the microfluidic devices needs to be considered. Nevertheless, the thermal design of the microfluidic device is far more simplified in comparison to a PCR chip: the bonding methods as well as the choice of materials (e.g. for a valve) are by far broader due to the lower temperature used. Temperature sensitive reagents can be used and the power consumption of the device is reduced.

Chemical reactions or latent heat storages are suitable to generate heat for isothermal amplification techniques at constant temperatures. Several chemical and especially exothermal reactions, partly in combination with phase-change material (PCM) to maintain temperature have been reported to produce heat and to keep foods and coffee warm or for the development of hand warmers. The released heat can also be used for isothermal amplification strategies. Especially LAMP was demonstrated to work in combination with such heating methods. The chemical reactions include (amongst others): the hydration of calcium oxide, calcium chloride or of magnesiumiron coatings as well as the oxidation of iron and the crystallization of sodium acetate. These exothermal reactions have the potential to reduce the complexity and the costs of a point-of-care device, are working independently from electricity and present a special option for the development of single-use systems.

In the future, isothermal amplification methods for nucleic acids integrated in portable, easy-to-use microsystems offer great opportunities for home-care DNA diagnostic devices.

\section{References}

1. Feynman RP (1992) There is plenty of room at the bottom. J Microelectromech Syst 1: 60-66.

2. Petersen KE (1982) Silicon as a mechanical material. Proceedings of the IEEE 70: $420-457$

3. Gerlach G, Dotze W (2008) Introduction to Microsystem Technology: A Guide for Students.

4. Dario P, Carrozza MC, Benvenuto A, Menciassi A (2000) Micro-systems in biomedical applications. J Micromech Microeng 10: 235-244.

5. Lisowski P, Zarzycki PK (2013) Microfluidic Paper-Based Analytical Devices (muPADs) and Micro Total Analysis Systems (muTAS): Development Applications and Future Trends. Chromatographia 76: 1201-1214.

6. Kim L (2013) Overview of the microfluidic diagnostics commercial landscape Methods Mol Biol 949: 65-83. 
Citation: Tröger V, Niemann K, Gärtig C, Kuhlmeier D (2015) Isothermal Amplification and Quantification of Nucleic Acids and its Use in Microsystems. J Nanomed Nanotechnol 6: 282. doi:10.4172/2157-7439.1000282

Page 15 of 19

7. Lei KF (2012) Microfluidic systems for diagnostic applications: a review. J Lab Autom 17: 330-347

8. Olasagasti F, Ruiz de Gordoa JC (2012) Miniaturized technology for protein and nucleic acid point-of-care testing. Transl Res 160: 332-345.

9. Foudeh AM, Fatanat Didar T, Veres T, Tabrizian M (2012) Microfluidic designs and techniques using lab-on-a-chip devices for pathogen detection for point-ofcare diagnostics. Lab Chip 12: 3249-3266.

10. Mullis K, Faloona F, Scharf S, Saiki R, Horn G, et al. (1986) Specific enzymatic amplification of DNA in vitro: the polymerase chain reaction. Cold Spring Harb Symp Quant Biol 51 Pt 1: 263-273.

11. Neethirajan S, Kobayashi I, Nakajima M, Wu D, Nandagopal S, et al. (2011) Microfluidics for food, agriculture and biosystems industries. Lab Chip 11 1574-1586.

12. Yoon JY, Kim B (2012) Lab-on-a-chip pathogen sensors for food safety Sensors (Basel) 12: 10713-10741.

13. Saiki RK, Scharf S, Faloona F, Mullis KB, Horn GT, et al. (1985) Enzymatic amplification of beta-globin genomic sequences and restriction site analysis for diagnosis of sickle cell anemia. Science 230: 1350-1354.

14. Kubista M, Andrade JM, Bengtsson M, Forootan A, Jonák J, et al. (2006) The real-time polymerase chain reaction. Mol Aspects Med 27: 95-125.

15. Botes M, de Kwaadsteniet M, Cloete TE (2013) Application of quantitative PCR for the detection of microorganisms in water. Anal Bioanal Chem 405: 91-108.

16. Hoorfar J (2011) Rapid detection, characterization, and enumeration of foodborne pathogens. APMIS Suppl : 1-24.

17. Maurin M (2012) Real-time PCR as a diagnostic tool for bacterial diseases. Expert Rev Mol Diagn 12: 731-754.

18. Sedlak RH, Jerome KR (2013) Viral diagnostics in the era of digital polymerase chain reaction. Diagn Microbiol Infect Dis 75: 1-4.

19. Northrup A, Gonzalez C, Lehew S, Hills R (2003) Micro Total Analysis Systems.

20. Wilding P, Shoffner MA, Kricka LJ (1994) PCR in a silicon microstructure. Clin Chem 40: 1815-1818.

21. Auroux PA, Koc Y, deMello A, Manz A, Day PJ (2004) Miniaturised nucleic acid analysis. Lab Chip 4: 534-546.

22. Chen L, Manz A, Day PJ (2007) Total nucleic acid analysis integrated on microfluidic devices. Lab Chip 7: 1413-1423

23. Focke M, Stumpf F, Roth G, Zengerle R, von Stetten F (2010) Centrifugal microfluidic system for primary amplification and secondary real-time PCR. Lab Chip 10: 3210-3212.

24. Marshall LA, Wu LL, Babikian S, Bachman M, Santiago JG (2012) Integrated printed circuit board device for cell lysis and nucleic acid extraction. Anal Chem 84: $9640-9645$

25. Ritzi-Lehnert M (2012) Development of chip-compatible sample preparation for diagnosis of infectious diseases. Expert Rev Mol Diagn 12: 189-206.

26. Schumacher S, Nestler J, Otto T, Wegener M, Ehrentreich-Förster E, et al (2012) Highly-integrated lab-on-chip system for point-of-care multiparameter analysis. Lab Chip 12: 464-473.

27. Woolley AT, Hadley D, Landre P, deMello AJ, Mathies RA, et al. (1996) Functional integration of PCR amplification and capillary electrophoresis in a microfabricated DNA analysis device. Anal Chem 68: 4081-4086.

28. Zhang R, Gong HQ, Zeng X, Lou C, Sze C (2013) A microfluidic liquid phase nucleic acid purification chip to selectively isolate DNA or RNA from low copy/ single bacterial cells in minute sample volume followed by direct on-chip quantitative PCR assay. Anal Chem 85: 1484-1491.

29. http://www.cepheid.com

30. http://www.fluidigm.com

31. www.microfluifdicchipshop.com

32. http://www.ivd-plattform.fraunhofer.de

33. http://www.thinxxs.com

34. Sato K, Tachihara A, Renberg B, Mawatari K, Sato K, et al. (2010) Microbead- based rolling circle amplification in a microchip for sensitive DNA detection. Lab Chip 10: 1262-1266.

35. Chang CC, Chen CC, Wei SC, Lu HH, Liang YH, et al. (2012) Diagnostic devices for isothermal nucleic acid amplification. Sensors (Basel) 12: 83198337.

36. Ahmad F, Hashsham SA (2012) Miniaturized nucleic acid amplification systems for rapid and point-of-care diagnostics: a review. Anal Chim Acta 733: 1-15.

37. Asiello PJ, Baeumner AJ (2011) Miniaturized isothermal nucleic acid amplification, a review. Lab Chip 11: 1420-1430.

38. Craw P, Balachandran W (2012) Isothermal nucleic acid amplification technologies for point-of-care diagnostics: a critical review. Lab Chip 12: 24692486.

39. Gill P, Ghaemi A (2008) Nucleic acid isothermal amplification technologies: a review. Nucleosides Nucleotides Nucleic Acids 27: 224-243.

40. Notomi T (2007) [Loop-mediated isothermal amplification]. Nihon Rinsho 65 957-961.

41. Nagamine K, Hase T, Notomi T (2002) Accelerated reaction by loop-mediated isothermal amplification using loop primers. Mol Cell Probes 16: 223-229.

42. Nagamine K, Watanabe K, Ohtsuka K, Hase T, Notomi T (2001) Loop-mediated isothermal amplification reaction using a nondenatured template. Clin Chem 47: 1742-1743.

43. Mori Y, Nagamine K, Tomita N, Notomi T (2001) Detection of loop-mediated isothermal amplification reaction by turbidity derived from magnesium pyrophosphate formation. Biochem Biophys Res Commun 289: 150-154.

44. Boubourakas IN, Fukuta S, Kyriakopoulou PE (2009) Sensitive and rapid detection of peach latent mosaic viroid by the reverse transcription loopmediated isothermal amplification. J Virol Methods 160: 63-68.

45. Mori Y, Kitao M, Tomita N, Notomi T (2004) Real-time turbidimetry of LAMP reaction for quantifying template DNA. J Biochem Biophys Methods 59: 145157.

46. Tomita N, Mori $\mathrm{Y}$, Kanda $\mathrm{H}$, Notomi T (2008) Loop-mediated isotherma amplification (LAMP) of gene sequences and simple visual detection of products. Nat Protoc 3: 877-882.

47. Soliman H, El-Matbouli M (2005) An inexpensive and rapid diagnostic method of Koi Herpesvirus (KHV) infection by loop-mediated isothermal amplification. Virol J 2: 83.

48. Yoda T, Suzuki Y, Yamazaki K, Sakon N, Kanki M, et al. (2007) Evaluation and application of reverse transcription loop-mediated isothermal amplification for detection of noroviruses. J Med Virol 79: 326-334.

49. Mori Y, Hirano T, Notomi T (2006) Sequence specific visual detection of LAMP reactions by addition of cationic polymers. BMC Biotechnol 6: 3 .

50. Fang X, Liu Y, Kong J, Jiang X (2010) Loop-mediated isothermal amplification integrated on microfluidic chips for point-of-care quantitative detection of pathogens. Anal Chem 82: 3002-3006.

51. Hataoka Y, Zhang L, Mori Y, Tomita N, Notomi T, et al. (2004) Analysis of specific gene by integration of isothermal amplification and electrophoresis on poly(methyl methacrylate) microchips. Anal Chem 76: 3689-3693.

52. Liu C, Mauk MG, Hart R, Qiu X, Bau HH (2011) A self-heating cartridge for molecular diagnostics. Lab Chip 11: 2686-2692.

53. Wang CH, Lien KY, Wang TY, Chen TY, Lee GB (2011) An integrated microfluidic loop-mediated-isothermal-amplification system for rapid sample pre-treatment and detection of viruses. Biosens Bioelectron 26: 2045-2052.

54. Wang CH, Lien KY, Wu JJ, Lee GB (2011) A magnetic bead-based assay for the rapid detection of methicillin-resistant Staphylococcus aureus by using a microfluidic system with integrated loop-mediated isothermal amplification. Lab Chip 11: 1521-1531.

55. Fang X, Chen H, Xu L, Jiang X, Wu W, et al. (2012) A portable and integrated nucleic acid amplification microfluidic chip for identifying bacteria. Lab Chip 12 1495-1499.

56. Hsieh K, Patterson AS, Ferguson BS, Plaxco KW, Soh HT (2012) Rapid sensitive, and quantitative detection of pathogenic DNA at the point of care through microfluidic electrochemical quantitative loop-mediated isothermal amplification. Angew Chem Int Ed Engl 51: 4896-4900. 
Citation: Tröger V, Niemann K, Gärtig C, Kuhlmeier D (2015) Isothermal Amplification and Quantification of Nucleic Acids and its Use in Microsystems. J Nanomed Nanotechnol 6: 282. doi:10.4172/2157-7439.1000282

Page 16 of 19

57. Ahmed MU, Nahar S, Safavieh M, Zourob M (2013) Real-time electrochemical detection of pathogen DNA using electrostatic interaction of a redox probe. Analyst 138: 907-915.

58. Chuang TL, Wei SC, Lee SY, Lin CW (2012) A polycarbonate based surface plasmon resonance sensing cartridge for high sensitivity HBV loop-mediated isothermal amplification. Biosens Bioelectron 32: 89-95

59. Chang WH, Yang SY, Lin CL, Wang CH, Li PC, et al. (2013) Detection of viruses directly from the fresh leaves of a Phalaenopsis orchid using a microfluidic system. Nanomedicine 9: 1274-1282.

60. Kaewphinit T, Arunrut N, Kiatpathomchai W, Santiwatanakul S, Jaratsing P, et al., (2013) Detection of Mycobacterium tuberculosis by using loop-mediated isothermal amplification combined with a lateral flow dipstick in clinical samples. Biomed Res Int: 926230.

61. Ahmad F, Seyrig D, Tourlousse R, Stedtfeld J, Tiedje, et al., (2011) A CCDbased fluorescence imaging system for real-time loop-mediated isotherma amplification-based rapid and sensitive detection of waterborne pathogens on microchips. Biomedical Microdevices 13: 929-937.

62. Duarte C, Salm E, Dorvel B, Reddy B Jr, Bashir R (2013) On-chip paralle detection of foodborne pathogens using loop-mediated isothermal amplification. Biomed Microdevices 15: 821-830.

63. Manage D, Chui L, Pilarski L (2013) Sub-microliter scale in-gel loop-mediated isothermal amplification (LAMP) for detection of Mycobacterium tuberculosis. Microfluidics and Nanofluidics 14: 731-741.

64. Liu C, Mauk M, Bau H (2011) A disposable, integrated loop-mediated isothermal amplification cassette with thermally actuated valves. Microfluidics and Nanofluidics 11: 209-220.

65. Liu C, Mauk MG, Hart R, Bonizzoni M, Yan G, et al. (2012) A low-cost microfluidic chip for rapid genotyping of malaria-transmitting mosquitoes. PLoS One 7: e42222.

66. Liu C, Geva E, Mauk M, Qiu X, Abrams WR, et al. (2011) An isotherma amplification reactor with an integrated isolation membrane for point-of-care detection of infectious diseases. Analyst 136: 2069-2076.

67. Piepenburg O, Williams CH, Stemple DL, Armes NA (2006) DNA detection using recombination proteins. PLoS Biol 4: e204

68. Lutz S, Weber P, Focke M, Faltin B, Hoffmann J, et al. (2010) Microfluidic labon-a-foil for nucleic acid analysis based on isothermal recombinase polymerase amplification (RPA). Lab Chip 10: 887-893.

69. Hakenberg S, Hügle M, Weidmann M, Hufert F, Dame G, et al. (2012) A phaseguided passive batch microfluidic mixing chamber for isothermal amplification. Lab Chip 12: 4576-4580.

70. Rohrman BA, Richards-Kortum RR (2012) A paper and plastic device for performing recombinase polymerase amplification of HIV DNA. Lab Chip 12 3082-3088.

71. Shen F, Davydova EK, Du W, Kreutz JE, Piepenburg O, et al. (2011) Digital isothermal quantification of nucleic acids via simultaneous chemical initiation of recombinase polymerase amplification reactions on SlipChip. Anal Chem 83: $3533-3540$

72. Greer S, Alexander GJ (1995) Viral serology and detection. Baillieres Clin Gastroenterol 9: 689-721.

73. Compton J (1991) Nucleic acid sequence-based amplification. Nature 350 91-92.

74. Furuta I (1989) Bacterial infection and rapid laboratory microbial methods. Rinsho Byori 37: 1096-1102.

75. Bennett BD (1997) Blood glucose determination: point of care testing. South Med J 90: 678-680.

76. Tudos AJ, Besselink GJ, Schasfoort RB (2001) Trends in miniaturized total analysis systems for point-of-care testing in clinical chemistry. Lab Chip 1: 83-95.

77. Ehrenkranz JR (2002) Home and point-of-care pregnancy tests: a review of the technology. Epidemiology 13 Suppl 3: S15-18.

78. Cohn LA, McCaw DL, Tate DJ, Johnson JC (2000) Assessment of five portable blood glucose meters, a point-of-care analyzer, and color test strips for measuring blood glucose concentration in dogs. J Am Vet Med Assoc 216 198-202.
79. Kievits T, van Gemen B, van Strijp D, Schukkink R, Dircks M, et al. (1991) NASBA isothermal enzymatic in vitro nucleic acid amplification optimized for the diagnosis of HIV-1 infection. J Virol Methods 35: 273-286.

80. Lamhoujeb S, Charest H, Fliss I, Ngazoa S, Jean J (2009) Real-time molecula beacon NASBA for rapid and sensitive detection of norovirus GII in clinical samples. Can J Microbiol 55: 1375-1380.

81. Morabito K, Kantor R, Tai W, Schreier L, Tripathi A (2013) Detection of HIV-1 minority variants containing the $\mathrm{K} 103 \mathrm{~N}$ drug-resistance mutation using a simple method to amplify RNA targets (SMART). J Mol Diagn 15: 401-412.

82. Zhao Y, Perlin DS (2013) Quantitative detection of Aspergillus spp. by real-time nucleic acid sequence-based amplification. Methods Mol Biol 968: 83-92.

83. Gulliksen A, Solli LA, Drese KS, Sörensen O, Karlsen F, et al. (2005) Paralle nanoliter detection of cancer markers using polymer microchips. Lab Chip 5 : 416-420.

84. Zhao X, Dong T (2012) Multifunctional sample preparation kit and on-chip quantitative nucleic acid sequence-based amplification tests for microbial detection. Anal Chem 84: 8541-8548.

85. Zhao X, Dong T, Yang Z, Karlsen H (2012) Aptamer-NASBA LOC as prospective tool for systemic therapy of cancer: quantitative detection on signaling molecular profiling. Conf Proc IEEE Eng Med Biol Soc 2012: 578-581.

86. McCalla SE, Ong C, Sarma A, Opal SM, Artenstein AW, et al. (2012) A simple method for amplifying RNA targets (SMART). J Mol Diagn 14: 328-335.

87. Gulliksen A, Keegan H, Martin C, O'Leary J, Solli LA, et al. (2012) Towards a "Sample-In, Answer-Out" Point-of-Care Platform for Nucleic Acid Extraction and Amplification: Using an HPV E6/E7 mRNA Model System. J Oncol 2012 905024.

88. Nugen SR, Asiello PJ, Connelly JT, Baeumner AJ (2009) PMMA biosenso for nucleic acids with integrated mixer and electrochemical detection. Biosens Bioelectron 24: 2428-2433

89. Esch MB, Locascio LE, Tarlov MJ, Durst RA (2001) Detection of viable Cryptosporidium parvum using DNA-modified liposomes in a microfluidic chip. Anal Chem 73: 2952-2958.

90. Dimov IK, Garcia-Cordero JL, O'Grady J, Poulsen CR, Viguier C, et al. (2008) Integrated microfluidic tmRNA purification and real-time NASBA device for molecular diagnostics. Lab Chip 8: 2071-2078.

91. Price CP, Kricka LJ (2007) Improving healthcare accessibility through point-ofcare technologies. Clin Chem 53: 1665-1675.

92. Smith MC, Steimle G, Ivanov S, Holly M, Fries DP (2007) An integrated portable hand-held analyser for real-time isothermal nucleic acid amplification. Anal Chim Acta 598: 286-294.

93. Dimov IK, Kijanka G, Park Y, Ducrée J, Kang T, et al. (2011) Integrated microfluidic array plate (iMAP) for cellular and molecular analysis. Lab Chip 11: $2701-2710$.

94. Fitch JC, Mirto GP, Geary KL, Byrne DW, Hines RL (1999) Point-of-care and standard laboratory coagulation testing during cardiovascular surgery: balancing reliability and timeliness. J Clin Monit Comput 15: 197-204.

95. Tang YW, Stratton C (2012) Advanced techniques in Diagnostic Microbiology.

96. Boulet GA, Micalessi IM, Horvath CA, Benoy IH, Depuydt CE, et al. (2010) Nucleic acid sequence-based amplification assay for human papillomavirus mRNA detection and typing: evidence for DNA amplification. J Clin Microbiol 48: $2524-2529$

97. Rajan A, Glorikian H (2009) Point-of-care diagnostics: market trends and growth drivers. Expert Opin Med Diagn 3: 1-4.

98. Yager P, Edwards T, Fu E, Helton K, Nelson K, et al. (2006) Microfluidic diagnostic technologies for global public health. Nature 442: 412-418.

99. Witt A, Petricevic L, Kaufmann U, Gregor H, Kiss H (2002) DNA hybridization test: rapid diagnostic tool for excluding bacterial vaginosis in pregnant women with symptoms suggestive of infection. J Clin Microbiol 40: 3057-3059.

100. Bearinger JP, Dugan LC, Baker BR, Hall SB, Ebert K, et al. (2011) Development and initial results of a low cost, disposable, point-of-care testing device for pathogen detection. IEEE Trans Biomed Eng 58: 805-808.

101. Curtis KA, Rudolph DL, Nejad I, Singleton J, Beddoe A, et al. (2012) Isotherma 
Citation: Tröger V, Niemann K, Gärtig C, Kuhlmeier D (2015) Isothermal Amplification and Quantification of Nucleic Acids and its Use in Microsystems. J Nanomed Nanotechnol 6: 282. doi:10.4172/2157-7439.1000282

amplification using a chemical heating device for point-of-care detection of HIV-1. PLoS One 7: e31432.

102. Vincent M, Xu Y, Kong $H$ (2004) Helicase-dependent isothermal DNA amplification. EMBO Rep 5: 795-800.

103. An L, Tang W, Ranalli TA, Kim HJ, Wytiaz J, et al. (2005) Characterization of a thermostable UvrD helicase and its participation in helicase-dependent amplification. J Biol Chem 280: 28952-28958.

104. Jeong YJ, Park K, Kim DE (2009) Isothermal DNA amplification in vitro: the helicase-dependent amplification system. Cell Mol Life Sci 66: 3325-3336.

105. Motré A, Li Y, Kong H (2008) Enhancing helicase-dependent amplification by fusing the helicase with the DNA polymerase. Gene 420: 17-22.

106. Goldmeyer J, Kong H, Tang W (2007) Development of a novel one-tube isothermal reverse transcription thermophilic helicase-dependent amplification platform for rapid RNA detection. J Mol Diagn 9: 639-44.

107. Vickerman P, Watts C, Alary M, Mabey D, Peeling RW (2003) Sensitivity requirements for the point of care diagnosis of Chlamydia trachomatis and Neisseria gonorrhoeae in women. Sex Transm Infect 79: 363-367.

108. Chow WH, McCloskey C, Tong Y, Hu L, You Q, et al., (2008) Application of isothermal helicase-dependent amplification with a disposable detection device in a simple sensitive stool test for toxigenic Clostridium difficile. J Mol Diagn 10: 452-458.

109. Huang S, Do J, Mahalanabis M, Fan A, Zhao L, et al. (2013) Low cost extraction and isothermal amplification of DNA for infectious diarrhea diagnosis. PLoS One 8: e60059.

110. Jordan JA, Ibe CO, Moore MS, Host C, Simon GL (2012) Evaluation of a manual DNA extraction protocol and an isothermal amplification assay for detecting HIV-1 DNA from dried blood spots for use in resource-limited settings. J Clin Virol 54: 11-14.

111. Li Y, Kumar N, Gopalakrishnan A, Ginocchio C, Manji R, et al., (2013) Detection and species identification of malaria parasites by isothermal tHDA amplification directly from human blood without sample preparation. $\mathrm{J}$ Mol Diagn 15: 634-641.

112. O'Neil D, Doseeva V, Rothmann T, Wolff J, Nazarenko I (2011) Evaluation of Chlamydia trachomatis and Neisseria gonorrhoeae detection in urine endocervical, and vaginal specimens by a multiplexed isothermal thermophilic helicase-dependent amplification (tHDA) assay. J Clin Microbiol 49: 41214125 .

113. Andresen D, von Nickisch-Rosenegk M, Bier FF (2009) Helicase-dependent amplification: use in OnChip amplification and potential for point-of-care diagnostics. Expert Rev Mol Diagn 9: 645-650.

114. Andresen D, von Nickisch-Rosenegk M, Bier FF (2009) Helicase dependent OnChip-amplification and its use in multiplex pathogen detection. Clin Chim Acta 403: 244-248.

115. Frech GC, Munns D, Jenison RD, Hicke BJ (2012) Direct detection of nasal Staphylococcus aureus carriage via helicase-dependent isothermal amplification and chip hybridization. BMC Res Notes 5: 430.

116. Ramalingam N, San T, Kai T, Mak M, Gong HQ (2009) Microfluidic devices harboring unsealed reactors for real-time isothermal helicase-dependent amplification. Microfluidics and Nanofluidics 7: 325-336.

117. Mahalanabis M, Do J, Zhang JY, Klapperich CM (2010) An integrated disposable device for DNA extraction and helicase dependent amplification. Biomed Microdevices 12: 353-359.

118. Zhang Y, Park S, Liu K, Tsuan J, Yang S, et al. (2011) A surface topography assisted droplet manipulation platform for biomarker detection and pathogen identification. Lab Chip 11: 398-406.

119. Tang W, Chow WH, Li Y, Kong H, Tang YW, et al. (2010) Nucleic acid assay system for tier II laboratories and moderately complex clinics to detect HIV in low-resource settings. J Infect Dis 201 Suppl 1: S46-51.

120. Kivlehan F, Mavré F, Talini L, Limoges B, Marchal D (2011) Real-time electrochemical monitoring of isothermal helicase-dependent amplification of nucleic acids. Analyst 136: 3635-3642.

121. Torres-Chavolla E, Alocilja EC (2011) Nanoparticle based DNA biosensor for tuberculosis detection using thermophilic helicase-dependent isothermal amplification. Biosensors and Bioelectronics 26: 4614-4618.
122. Doseeva V, Forbes T, Wolff J, Khripin Y, O'Neil D, et al., (2011) Multiplex isothermal helicase-dependent amplification assay for detection of Chlamydia trachomatis and Neisseria gonorrhoeae. Diagn Microbiol Infect Dis 71: 354-365.

123. Kim HJ, Tong Y, Tang W, Quimson L, Cope VA, et al. (2011) A rapid and simple isothermal nucleic acid amplification test for detection of herpes simplex virus types 1 and 2. J Clin Virol 50: 26-30

124. Tong $\mathrm{Y}$, McCarthy K, Kong H, Lemieux B (2012) Development and comparison of a rapid isothermal nucleic acid amplification test for typing of herpes simplex virus types 1 and 2 on a portable fluorescence detector. J Mol Diagn 14: 569-576.

125. Walker GT, Fraiser MS, Schram JL, Little MC, Nadeau JG, et al. (1992) Strand displacement amplification--an isothermal, in vitro DNA amplification technique. Nucleic Acids Res 20: 1691-1696.

126. Walker GT, Little MC, Nadeau JG, Shank DD (1992) Isothermal in vitro amplification of DNA by a restriction enzyme/DNA polymerase system. Proc Natl Acad Sci U S A 89: 392-396.

127. Walker GT, Nadeau JG, Spears PA, Schram JL, Nycz CM, et al., (1994) Multiplex strand displacement amplification (SDA) and detection of DNA sequences from Mycobacterium tuberculosis and other mycobacteria. Nucleic Acids Res 22: 2670-2677.

128. Cogswell FB, Bantar CE, Hughes TG, Gu Y, Philipp MT (1996) Host DNA can interfere with detection of Borrelia burgdorferi in skin biopsy specimens by PCR. J Clin Microbiol 34: 980-982.

129. Sachse S, Straube E, Lehmann M, Bauer M, Russwurm S, et al., (2009) Truncated human cytidylate-phosphate-deoxyguanylate-binding protein for improved nucleic acid amplification technique-based detection of bacterial species in human samples. J Clin Microbiol 47: 1050-1057.

130. Brunham RC, Rey-Ladino J (2005) Immunology of Chlamydia infection: implications for a Chlamydia trachomatis vaccine. Nat Rev Immunol 5: 149-161.

131. He Y, Zeng K, Zhang S, Gurung AS, Baloda M, et al., (2011) Visual detection of gene mutations based on isothermal strand-displacement polymerase reaction and lateral flow strip. Biosens Bioelectron 31: 310-315.

132. Burns MA, Johnson BN, Brahmasandra SN, Handique K, Webster JR, et al. (1998) An integrated nanoliter DNA analysis device. Science 282: 484-487.

133. Yang JM, Bell J, Huang Y, Tirado M, Thomas D, et al. (2002) An integrated, stacked microlaboratory for biological agent detection with DNA and immunoassays. Biosens Bioelectron 17: 605-618.

134. Westin L, Xu X, Miller C, Wang L, Edman CF, et al. (2000) Anchored multiplex amplification on a microelectronic chip array. Nat Biotechnol 18: 199-204.

135. Little MC, Andrews J, Moore R, Bustos S, Jones L, et al., (1999) Strand displacement amplification and homogeneous real-time detection incorporated in a second-generation DNA probe system, BDProbeTecET. Clin Chem 45 777-784.

136. Eksi F, Dikensoy E, Gayyurhan ED, Balci I, Balat O, et al. (2011) The prevalence of Chlamydia trachomatis and Neisseria gonorrhoeae in the endocervical swab specimens of symptomatic, asymptomatic and infertile women in Turkey. Arch Gynecol Obstet 283: 1349-1355.

137. Fang J, Husman C, DeSilva L, Chang R, Peralta L (2008) Evaluation of selfcollected vaginal swab, first void urine, and endocervical swab specimens for the detection of Chlamydia trachomatis and Neisseria gonorrhoeae in adolescent females. J Pediatr Adolesc Gynecol 21: 355-360.

138. Hung HC, Chan CH, Tsao SM, Chen SC, Wu TC, et al. (2012) Effectiveness of the BDProbeTec ET system for detection of Mycobacterium tuberculosis complex in sputum and bronchoalveolar lavage specimens. Braz J Infect Dis 16: 242-249.

139. Marshall R, Chernesky M, Jang D, Hook EW, Cartwright CP, et al. (2007) Characteristics of the m2000 automated sample preparation and multiplex real-time PCR system for detection of Chlamydia trachomatis and Neisseria gonorrhoeae. J Clin Microbiol 45: 747-751.

140. Piersimoni C, Bornigia S, Gherardi G (2012) Performance of a commercial nucleic acid amplification test with extrapulmonary specimens for the diagnosis of tuberculosis. Eur J Clin Microbiol Infect Dis 31: 287-293.

141. Van Der Pol B, Ferrero DV, Buck-Barrington L, Hook E, Lenderman C, et al., (2001) Multicenter evaluation of the BDProbeTec ET System for detection of Chlamydia trachomatis and Neisseria gonorrhoeae in urine specimens, female endocervical swabs, and male urethral swabs. J Clin Microbiol 39: 1008-1016. 
Citation: Tröger V, Niemann K, Gärtig C, Kuhlmeier D (2015) Isothermal Amplification and Quantification of Nucleic Acids and its Use in Microsystems. J Nanomed Nanotechnol 6: 282. doi:10.4172/2157-7439.1000282

Page 18 of 19

142. Hellyer TJ, Nadeau JG (2004) Strand displacement amplification: a versatile tool for molecular diagnostics. Expert Rev Mol Diagn 4: 251-261

143. Banér J, Nilsson M, Mendel-Hartvig M, Landegren U (1998) Signa amplification of padlock probes by rolling circle replication. Nucleic Acids Res 26: 5073-5078.

144.Liu D, Daubendiek SL, Zillman MA, Ryan K, Kool ET (1996) Rolling Circle DNA Synthesis: Small Circular Oligonucleotides as Efficient Templates for DNA Polymerases. J Am Chem Soc 118: 1587-1594.

145. Conze T, Göransson J, Razzaghian HR, Ericsson O, Oberg D, et al. (2010) Single molecule analysis of combinatorial splicing. Nucleic Acids Res 38: e163.

146. Johne R, Müller H, Rector A, van Ranst M, Stevens H (2009) Rolling-circle amplification of viral DNA genomes using phi29 polymerase. Trends Microbio 17: 205-211.

147.Zhao W, Brook MA, Li Y (2008) Periodic assembly of nanospecies on repetitive DNA sequences generated on gold nanoparticles by rolling circle amplification. Methods Mol Biol 474: 79-90.

148. Zhang DY, Zhang W, Li X, Konomi Y (2001) Detection of rare DNA targets by isothermal ramification amplification. Gene 274: 209-216.

149. Murakami T, Sumaoka J, Komiyama M (2009) Sensitive isothermal detection of nucleic-acid sequence by primer generation-rolling circle amplification. Nucleic Acids Res 37: e19.

150. Murakami T, Sumaoka J, Komiyama M (2012) Sensitive RNA detection by combining three-way junction formation and primer generation-rolling circle amplification. Nucleic Acids Res 40: e22.

151. Mahmoudian L, Kaji N, Tokeshi M, Nilsson M, Baba Y (2008) Rolling circle amplification and circle-to-circle amplification of a specific gene integrated with electrophoretic analysis on a single chip. Anal Chem 80: 2483-2490.

152. Mahmoudian L, Melin J, Mohamadi MR, Yamada K, Ohta M, et al. (2008) Microchip electrophoresis for specific gene detection of the pathogenic bacteria $\mathrm{V}$. cholerae by circle-to-circle amplification. Anal Sci 24: 327-332.

153. Wu M, Piccini M, Koh CY, Lam KS, Singh AK (2013) Single cell microRNA analysis using microfluidic flow cytometry. PLoS One 8: e55044.

154. Konry T, Smolina I, Yarmush JM, Irimia D, Yarmush ML (2011) Ultrasensitive detection of low-abundance surface-marker protein using isothermal rolling circle amplification in a microfluidic nanoliter platform. Small 7: 395-400.

155.Zhao W, Cui CH, Bose S, Guo D, Shen C, et al. (2012) Bioinspired multivalent DNA network for capture and release of cells. Proc Natl Acad Sci U S A 109: 19626-19631.

156. Barbee KD, Chandrangsu M, Huang X (2011) Fabrication of DNA polymer brush arrays by destructive micropatterning and rolling-circle amplification. Macromol Biosci 11: 607-617.

157. Juul S, Ho YP, Stougaard M, Koch J, Andersen FF, et al. (2011) Microfluidicsmediated isothermal detection of enzyme activity at the single molecule level. Conf Proc IEEE Eng Med Biol Soc 2011: 3258-3261.

158. Yan J, Song S, Li B, Zhang Q, Huang Q, et al. (2010) An on-nanoparticle rolling-circle amplification platform for ultrasensitive protein detection in biological fluids. Small 6: 2520-2525.

159. Yan J, Su S, He S, He Y, Zhao B, et al. (2012) Nano rolling-circle amplification for enhanced SERS hot spots in protein microarray analysis. Anal Chem 84: 9139-9145.

160. Stougaard M, Juul S, Andersen FF, Knudsen BR (2011) Strategies for highly sensitive biomarker detection by Rolling Circle Amplification of signals from nucleic acid composed sensors. Integr Biol (Camb) 3: 982-992.

161. Mazutis L, Araghi AF, Miller OJ, Baret JC, Frenz L, et al. (2009) Droplet-based microfluidic systems for high-throughput single DNA molecule isothermal amplification and analysis. Anal Chem 2009. 81: 4813-4821.

162. Schopf E, Fischer NO, Chen Y, Tok JB (2008) Sensitive and selective viral DNA detection assay via microbead-based rolling circle amplification. Bioorg Med Chem Lett 18: 5871-5874.

163. Nallur G, Luo C, Fang L, Cooley S, Dave V, et al. (2001) Signal amplification by rolling circle amplification on DNA microarrays. Nucleic Acids Res 29: E118.
164. Wharam SD, Hall MJ, Wilson WH (2007) Detection of virus mRNA within infected host cells using an isothermal nucleic acid amplification assay: marine cyanophage gene expression within Synechococcus sp. Virol J 4: 52.

165. Hall MJ, Wharam SD, Weston A, Cardy DL, Wilson WH (2002) Use of signal-mediated amplification of RNA technology (SMART) to detect marine cyanophage DNA. Biotechniques 32: 604-606, 608-11.

166. Li Y, Kim HJ, Zheng C, Chow WH, Lim J, et al. (2008) Primase-based whole genome amplification. Nucleic Acids Res 36: e79.

167. Aw W, Lezhava A, Hayashizaki Y, Ishikawa T (2011) A new trend in personalized medicine: rapid detection of SNPs in drug transporter genes by the SmartAmp method. Clin Pharmacol Ther 89: 617-620.

168. Ishikawa T, Hayashizaki Y (2013) Clinical SNP detection by the SmartAmp method. Methods Mol Biol 1015: 55-69.

169. Mitani Y, Lezhava A, Kawai Y, Kikuchi T, Oguchi-Katayama A, et al. (2007) Rapid SNP diagnostics using asymmetric isothermal amplification and a new mismatch-suppression technology. Nat Methods 4: 257-262

170. Enokida Y, Shimizu K, Atsumi J, Lezhava A, Tanaka Y, et al. (2013) Rapid detection of SNP (c.309T>G) in the MDM2 gene by the Duplex SmartAmp method. PLoS One 8: e60151.

171. Inoue Y, Mori T, Toyoda Y, Sakurai A, Ishikawa T, et al. (2010) Correlation of axillary osmidrosis to a SNP in the ABCC11 gene determined by the Smart Amplification Process (SmartAmp) method. J Plast Reconstr Aesthet Surg 63 : 1369-1374.

172. Kawai Y, Kimura Y, Lezhava A, Kanamori H, Usui K, et al. (2012) One-step detection of the 2009 pandemic influenza $A(H 1 N 1)$ virus by the RT-SmartAmp assay and its clinical validation. PLoS One 7: e30236.

173. Jung C, Chung JW, Kim UO, Kim MH, Park HG (2011) Real-time colorimetric detection of target DNA using isothermal target and signaling probe amplification and gold nanoparticle cross-linking assay. Biosens Bioelectron 26: 1953-1958.

174.Zhang J, Tian Q, Zhu SF, Zhao WJ, Liu FQ (2012) Rapid on-site detection of Acidovorax citrulli by cross-priming amplification. Mol Cell Probes 26: 175-176.

175. Artaza O, Enríquez G, Hinrichsen M, Eimbcke F (1988) Echocardiographic diagnosis of intracardiac tumors. Rev Chil Pediatr 59: 318-321.

176. Ma C, Zhao C, Ge Y, Shi C (2012) Aptameric molecular switch for cascade signal amplification. Clin Chem 58: 384-390.

177. Connolly AR, Trau M (2010) Isothermal detection of DNA by beacon-assisted detection amplification. Angew Chem Int Ed Engl 49: 2720-2723.

178. Van Ness J, Van Ness LK, Galas DJ (2003) Isothermal reactions for the amplification of oligonucleotides. Proc Natl Acad Sci U S A 100: 4504-4509.

179. Jia H, Li Z, Liu C, Cheng Y (2010) Ultrasensitive detection of microRNAs by exponential isothermal amplification. Angew Chem Int Ed Engl 49: 5498-5501.

180. Wen Y, Xu Y, Mao X, Wei Y, Song H, et al. (2012) DNAzyme-based rollingcircle amplification DNA machine for ultrasensitive analysis of microRNA in Drosophila larva. Anal Chem 84: 7664-7669.

181. Ménová P, Hocek M (2012) Preparation of short cytosine-modified oligonucleotides by nicking enzyme amplification reaction. Chem Commun (Camb) 48: 6921-6923.

182. Ménová P, Raindlová V, Hocek M (2013) Scope and limitations of the nicking enzyme amplification reaction for the synthesis of base-modified oligonucleotides and primers for PCR. Bioconjug Chem 24: 1081-1093.

183. Spenlinhauer T, Estock M, McFadd T, Kovacs S, Hoyos G, et al. (2009) Nicking Enzyme Amplification Reaction (NEAR), an Isothermal Nucleic Acid Based Technology for Point-of-Testing of Plant Pathogens in American Phytopathological Society Annual Meeting.

184. You G, Lin H, Jing W, Huayan Z (2006) Method for amplifying target nucleic acid sequence by nickase, and kit for amplifying target nucleic acid sequence and its use.

185. Tong Y (2014) 3-Isothermal amplification of specific sequences, in Biological Identification.

186. Mukai H, Uemori T, Takeda O, Kobayashi E, Yamamoto J, et al. (2007) Highly efficient isothermal DNA amplification system using three elements of 5'-DNA- 
Citation: Tröger V, Niemann K, Gärtig C, Kuhlmeier D (2015) Isothermal Amplification and Quantification of Nucleic Acids and its Use in Microsystems. J Nanomed Nanotechnol 6: 282. doi:10.4172/2157-7439.1000282

RNA-3' chimeric primers, RNaseH and strand-displacing DNA polymerase. J Biochem 142: 273-281.

187. Shimada M, Hino F, Sagawa H, Mukai H, Asada K, et al. (2002) Development of the detection system for Mycobacterium tuberculosis DNA by using the isothermal DNA amplification method ICAN. Rinsho Byori 50: 528-532.

188. Shimada M, Hino F, Yamamoto J, Mukai H, Hosobe T, et al. (2003) Evaluation of the simultaneous detection system for Chlamydia trachomatis/Neisseria gonorrhoeae DNA by the isothermal and chimeric primer-initiated amplification of nucleic acids (ICAN)]. Rinsho Byori 51: 1061-1067.

189. Urasaki N, Kawano S, Mukai H, Uemori T, Takeda O, et al. (2008) Rapid and sensitive detection of Candidatus Liberibacter asiaticus by cycleave isothermal and chimeric primer-initiated amplification of nucleic acids. Journal Of General Plant Pathology 2: 151-155.
190. Inami H, Tsuge K, Matsuzawa M, Sasaki Y, Togashi S, et al. (2009) Semiautomated bacterial spore detection system with micro-fluidic chips for aeroso collection, spore treatment and ICAN DNA detection. Biosens Bioelectron 24 3299-3305.

191. Jung C, Chung JW, Kim UO, Kim MH, Park HG (2010) Isothermal target and signaling probe amplification method, based on a combination of an isothermal chain amplification technique and a fluorescence resonance energy transfer cycling probe technology. Anal Chem 82: 5937-5943.

192. Kurn N, Chen P, Heath JD, Kopf-Sill A, Stephens KM, et al. (2005) Novel isothermal, linear nucleic acid amplification systems for highly multiplexed applications. Clin Chem 51: 1973-1981.

193. Dirks RM, Pierce NA (2004) Triggered amplification by hybridization chain reaction. Proc Natl Acad Sci USA 101: 15275-15278. 